\title{
DIGITALCOMMONS
}

@WAYNESTATE —

Wayne State University

$1-1-1972$

\section{The Contracts Provisions of the Restatement (Second): An Analysis and a Critique}

Robert Allen Sedler

Wayne State University, rsedler@wayne.edu

\section{Recommended Citation}

Robert Allen Sedler, The Contracts Provisions of the Restatement of Conflict of Laws (Second): An Analysis and a Critique, 72 Colum. L. Rev. 279 (1972).

Available at: http://digitalcommons.wayne.edu/lawfrp/38 


\title{
THE CONTRACTS PROVISIONS OF THE RESTATEMENT (SECOND): AN ANALYSIS AND A CRITIQUE
}

\author{
ROBERT ALLEN SEDLER*
}

\section{INTRODUCTION}

It is standard practice to refer to contracts as "the most complex and confused area of choice of law problems,"1 and the drafters of the Restatement (Second) are no exception. In their view:

This complexity results in part from the wide uses of contracts, the lawyer's universal tool in business and personal affairs. This complexity is increased by the many different kinds of contracts and of issues involving contracts and by the many relationships a single contract may have to two or more states. ${ }^{2}$

On the other hand, Professor Ehrenzweig, a severe and indefatigable critic of the new Restatement, ${ }^{3}$ maintains that the confusion "is one of language rather than substance," and is the product of "that brief conceptualistic era which found comfort in dogmatic formulas based on "first principles of legal thinking." "He contends that in practice courts have followed "true rules" in contract cases, as in all others, ${ }^{5}$ and that these "true rules" are refiected in a "rule of validity" as between parties of equal bargaining power, ${ }^{8}$ protection of the adherent where bargaining power is unequal, ${ }^{7}$ and application of the law of the forum with respect to incidents of the contract. ${ }^{8}$ Whether or not one agrees with Professor Ehrenzweig's view that the case law supports his conclusion as to the "true rule,"9 I think that he has indeed hit upon the source of the confusion: the attempt to resolve conflicts problems in terms of analytical doctrine rather than with reference to the practice of the courts in dealing with real controversies. If this is so, the contracts provisions of the Second Restate-

* Professor of Law, University of Kentucky. A.B., J.D., University of Pittsburgh.

1. R. Weintraub, ComMrentary on the Conflict of LaWs 263 \& n.1 (1971).

2. Restatement (SECOND) OF CONFLict of LAws, Introductory Note to ch. 8, at 557 (1971) [hereinafter cited as RESTATEMENT (SECOND)].

3. See Ehrenzweig, The Second Conflicts Restatement: $A$ Last Appeal for Its Withdrawal, 113 U. PA. L. REv. 1230 (1965); Ehrenzweig, American Conflicts Laze in Its Historical Perspective: Should the Restatement Be Continued, 103 U. PA. L. REv. 133 (1954).

4. A. EHRENZWEIG, CONFLICT OF LAWS 453 (1962).

5. Id. at 307-09. See generally Ehrenzweig, $A$ Proper Law in a Proper Forum: $A$ "Restatement" of the "Lex Fori Approach" 18 OKLA. L. REv. 340 (1965); Ehrenzweig, Choice of Law: Current Doctrine and "True Rules," 49 CALIF. L. REv. 240 (1961).

6. A. EHRENZWVIG, supra note 4, at 466-67.

7. $I \dot{d}$. at $454-58$.

8. Id. at 490 .

9. For the observation that it does not, at least with respect to the Statute of Frauds, see Currie, Ehrenzweig and the Statute of Frafls: An Inquiry into the "Rule of Validation," 18 OKA.A. L. REV. 243 (1965), 
ment will not help to remedy the confusion and may even serve to compound it by substituting one set of terminological abstractions for another.

The general conception of the Restatement (Second), as distinguished from the original Restatement, is that conflicts problems will best be resolved by a combination of several broad, flexible rules that are "fluid in operation" and a "large number of relatively narrow rules that will be applicable only in precisely defined situations." 10 The contracts rules, which apparently were the most difficult to formulate, 11 follow this model closely. There are two "basic rules," application of which depends upon whether the parties have attempted to make an express choice of law, and a series of specific rules applying the basic provisions to particular kinds of contracts and particular issues. ${ }^{12}$ Under section 187 the parties are permitted to choose the governing law, subject to certain limitations. Where the parties have not made an effective choice of law, section 188 applies, and it provides that their rights and duties "are determined by the local law of the state which, with respect to that issue, has the most significant relationship to the transaction and the parties under the principles stated in $\S 6 . " 13$ Section 6 sets forth what may be called underlying choice-of-law principles. ${ }^{14}$ While all of these principles are potentially applicable to contract cases, the most important ones in such a context are likely to be the protection of justified expectations and the promotion of certainty, predictability and uniformity of result.15 The factual contacts to be taken into account under section 188 in applying the principles of section 6 to determine the state of the most significant relationship include:

(a) the place of contracting,

(b) the place of negotiation of the contract,

(c) the place of performance,

(d) the location of the subject matter of the contract, and

(e) the domicile, residence, nationality, place of incorporation and place of business of the parties. ${ }^{18}$

These contacts are to be evaluated according to their relative importance with

10. Reese, Conflict of Laws and the Restatement Second, 28 LAW \& Contemp. Prob. 679, 681 (1963). Compare RESTATEMENT (SECOND) \$\$ 186-88 with \$\$ 189-220.

11. See Reese, Contracts and the Restatement of Conflict of Lazes, Second, 9 InT's \& COMP. L.Q. 531, 533-34 (1960).

12. See notes 18-30 infra and accompanying text.

13. The Restatement generally excludes consideration of the chosen state's conflict rules. See Restatement (SeconD), Explanatory Notes \& 8, comments $a-1$, at 22-30. I have contended that where the state whose law is sought to be used as a model would decide the very case in accordance with the forum's substantive law, the forum ought not to displace its law. See Sedler, Babcock v. Jackson in Kentucky: Judicial Method and the Policy-Centered Conflict of Lazes, 56 KY. L.J. 27, 95-101 (1967).

14. In the rare event that there is a statutory directive as to choice of law, the forum must, of course, follow it See RESTATEMENT (SEcoND) \& 6(1) and Explanatory Notes $\$ 6(1)$, comments $a$ and $b$, at 11 ; Oxford Consumer Discount Co. v. Stefanelli, 102 N.J. Super. 549, 564, 246 A.2d 460, 468 (1968). See also note 253 infra.

15. See Reese, stipra note 10, at 697 . See generally Restatement (Second), Explanatory Notes \& 188 , comments $b-f$, at $576-83$.

16. Restatement (Second) \& 188(2). 
respect to the particular issue. If, however, the place of negotiation and the place of performance are in the same state, that state is ordinarily considered to have the most significant relationship to the contract. ${ }^{17}$

After setting forth in section 186 the basic principle that the law chosen by the parties or-in the absence of an effective choice-the law of the state having the most significant relationship will govern the contract, ${ }^{18}$ the $R e-$ statement proceeds to consider specific kinds of agreements to which this general standard applies. For each type of contract, a detailed rule is laid down in the form of a presumption that a particular locality will in fact be found to have the most significant relationship. ${ }^{19}$ These presumptions are, however, qualified with the proviso: "unless, with respect to the particular issue, some other state has a more significant relationship under the principles stated in $\$ 6$ to the transaction and the parties . ..."20 The Restatement then elaborates upon the issues that are to be determined by the basic principle of section 186: capacity to contract, ${ }^{21}$ formalities, ${ }^{22}$ essential validity, ${ }^{23}$ the effect of misrepresentation, duress, undue influence and mistake, ${ }^{24}$ illegality, ${ }^{25}$ the nature and extent of obligations ${ }^{26}$ and the measure of recovery. ${ }^{27}$ Usurious contracts are treated separately. ${ }^{28}$ There are also special rules as to the law determining the construction of words used in the contract $^{29}$ and the details. of performance. ${ }^{30}$

17. Id. $\S 188(3)$. Exceptions to this rule may be found in the instance of the special types of contracts covered in sections $189-97$ and situations in which validity is at issue under section 198(2) (a party has contractual capacity under the law of his domicile), section 199(2) (the formalities satisfy the requirements of the place of execution), and section 203 (rule of validation in usury defenses).

18. Section 186 in turn refers to the rules of sections 187 and 188.

19. These may be summarized as follows:

(1) Land contracts-the law of the situs. \$§ 189-90.

(2) Contracts to sell interests in chattels-the place of delivery. \& 191.

(3) Life insurance contracts-the domicile of the insured. \$ 192 .

(4) Contracts of fire, surety, or casualty insurance-the principal location of the insured risk. \& 193.

(5) Contracts of suretyship-the law governing the principal obligation. ₹ 194.

(6) Contracts for the repayment of money-the place of repayment. \& 195 .

(7) Contracts for the rendition of services-the place where the major portion of the services are to be rendered. \& 196.

(8) Contracts of transportation-place of departure or dispatch. \$197.

20. See Restatement (Second) §\$ 189-97.

21. Id. $\S 198$. (When the party has capacity under the law of his domicile, his capacity will be upheld.)

22. Id. $\$ 199$. (Formalities that meet the requirements of the place where the parties execute the contract will usually be acceptable.)

23. Id. $\S 200$.

24. Id. § 201.

25. Id. $\S 202$. (When performance is illegal in the place of performance, the contract will usually be denied enforcement.)

26. Id. § 205.

27. Id. § 207.

28. $I d$. $\S 203$. They will be discussed independently in this article. See notes 216-79 infra and accompanying text.

29. Id. \$ 204. The forum is directed first to try to determine the actual intention of the parties. If this fails, the contract is to be construed in accordance with the basic rule, i.e., the law chosen or the law of the state of the inost significant relationship.

30. Id. $\$ 206$. The details of performance are determined by the law of the place of 
According to Professor Reese, the Reporter for the Restatement (Second), the contracts provisions incorporate four major changes from the original Restatement. First, "perhaps the most important change" is that the parties are now given wide power to choose the law that will govern the validity of their contract. ${ }^{31}$ Second, in the absence of an effective choice by the parties, "the validity of a contract is no longer subjected inevitably and unalterably to the law of the place of contracting," but instead is governed by the law of the state to which it has the most significant relationship. ${ }^{32}$ Third, the first Restatement "laid down rules applicable to the entire field of contracts and made no attempt to distinguish between particular kinds of contracts," whereas the Restatement (Second) "proceeds to discuss particular kinds of contracts where it is possible to state on the basis of existing knowledge that, in the absence of an effective choice of law by the parties, a given contract will be given greatest weight in the selection of the State of the governing law."33 The fourth major change is that the new Restatement makes no sharp distinction between matters of validity and matters of performance, looking in both instances to the same law except for the details of performance. ${ }^{34}$

Professor Reese has ably and effectively stated the justification for the Second Restatement's approach to contracts, particularly in comparison to an approach based upon interest analysis ${ }^{35}$ or one based upon a rule of validation. ${ }^{86}$ It seems appropriate in the present article to set out this justification fully in the words of Professor Reese:

Experience has shown that this large and complicated area cannot adequately be handled by a few single rules. What is needed instead is a large number of rules that are each directed to a relatively narrow situation. Experience to date is not sufficient to permit the formulation of many such rules at the present time. ... It would, of course, be far easier if it were possible to say that consideration need be given to only one of the relevant policies, as that a court should apply its own law when to do so would further a local interest or, in order to protect the expectations of the parties, should apply a law which will validate the contract. Such a view, however, would vastly oversimplify the problem and would probably prove to be as incorrect

performance. See id., Explanatory Notes $\$ 206$, comment b, at 669-70 (examples of what constitute "details of performance" within the meaning of this rule).

There are also special topics on Assignment of Contractual Rights ( $\$$ 208-11), Discharge ( $\$$ 212-13), Negotiable Instruments ( $\$ \S 214-17$ ), Commercial Arbitration ( $\$ 218-20$ ), and Restitution ( $\$ 221$ ). These areas as such will not be discussed in the present article.

31. Reese, supra note 11, at 534.

32. Id. at 537 .

33. Id. at 538 .

34. Id. at 539-40. The special rule as to usury, REstatenent (SEcond) § 203, is also a departure froin the approach of the original Restatement, which laid down no special rule in this area, thus treating usury in the same manner as any other issue going to the validity of the contract.

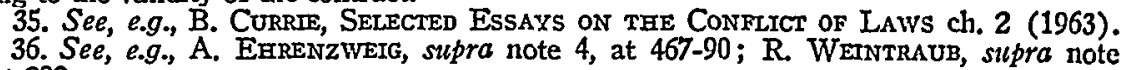
1 , at 292 . 
as the equally simple, and much criticized, rule of the original Restatement that the validity of a contract is governed by the law of the place of contracting.

There is no easy short cut. In each case, all of the policies must be considered and a choice-of-law rule developed that will give effect to what are the most important policies for the precise purpose at hand. It is felt as a result that the Restatement cannot usually do more in the case of contracts which contain no choice-of-law provision than to state the general principle of state of most significant relationship in the black letter rule and then to mention in the comments the more important considerations that should motivate the courts in arriving at a decision and in general to give whatever guidance is possible. At the very least, such black letter rules and comments will not mislead an unwary court or litigant into believing that the area is governed by well-settled rules. ${ }^{37}$

Whatever may be their deficiencies, the contract rules of the Restatement (Second) do not lack well-reasoned and articulate justification.

Nor, on the other hand, do they lack critics. Professor Ehrenzweig has said:

The Second Restatement formula can be used to support virtually any result and is thus bound to hamper the sound development of the common law by saving the court the difficult but necessary effort of articulating those true motivations which are of course the very elements of growing rules. ${ }^{38}$

In referring to the chapter on contracts as indicative of the Second Restatement's general approach, Professor Cavers has observed:

Most evident, I believe, is the want of a consistent conception of the choice-of-law problem. The impression grows that each section of the old Restatement has been read in the light of the supervening cases, and the old provisions cast out, modified, or left intact as the opinions, taken at face value, seemed to require. ... But in this period of changing idcas and interests, naturally the impact of the cases has been erratic. In Restatement Second, the result of reflecting them has been an erratic pattern, one lacking in internal coherence but nonetheless providing openings for imaginative, articulate courts to exploit in the future. ${ }^{39}$

And in his recent treatise, Professor Weintraub has voiced strong criticisms of the Second Restatement's approach to express choice of law ${ }^{40}$ and to the concept of the state of the most significant relationship as "governing law."41

I propose in this article to analyze the contracts provisions of the Restatement (Second) -and choice-of-law questions in the field of contracts generally

37. Reese, sitpra note 10 , at $697-99$.

38. Ehrenzweig, The Second Conflicts Restatement, supra note 3, at 1241.

39. Cavers, RE-restating the Conflict of Laws: The Chapter on Contracts, in XXtH CentuRY CoMrparative and Conflicts Law 349, 364 (1961).

40. R. WeInTraUB, supra note 1 , at 273-75.

41. $I d$. at $276-80$. 
-from the perspective of what I have called "judicial method and the policycentered conflict of laws." This methodology, which I have elaborated more fully elsewhere, ${ }^{42}$ may be summarized briefly as follows: (1) The basic law is the law of the forum; it will be applied in the absence of considerations requiring its displacement by the law of another state. (2) The court should in each instance determine whether such displacement is warranted with reference to the fact-law pattern of the case at bar. (3) Displacement should occur only when application of the forum's law either would defeat the legitimate expectations of the parties or would violate the interests of states that, under the circumstances presented, the forum should recognize. ${ }^{43}$ This system has its genesis in the methodology of interest analysis developed by Professor Currie.44 Although I have thus far utilized this approach primarily in the context of torts cases, I believe that it is equally relevant to contracts issues.

In terms of its methodology and orientation, the "policy-centered conflict of laws" is directly antithetical to the "rules" approach of the Restatement (Second). The emphasis of policy analysis on the law of the forum as the basic law and on the responsibility of the court to decide the case in light of its particular law-fact pattern is at odds with the Restatement's notion that, irrespective of the forum in which they are brought, all cases should be decided in the same way through correct application of the designated "rule." It is particularly significant in this connection that the Restatement discusses all questions from the vantage point of a "disinterested third state." 45 In practice, however, few cases arise in a purely disinterested forum. A basic premise of interest analysis is that the result in a given case may well depend upon the forum in which the action is filed, since the application of the forum's law is the only rational inethod by which a true conflict can be resolved. ${ }^{46}$

My own view of the Restatement (Second) is not a sympathetic one, and my earlier contention that it has substituted "many complex rules" for the "few simple ones" of the original Restatement, ${ }^{47}$ would seem to be particularly borne out in contracts provisions. More importantly, its "rules methodology" is inconsistent with an analysis of conflicts problems in terms of policy and

42. See Sedler, supra note 13; Sedler, Characterization, Identification of the Problem Area, and the Policy-Centered Conflict of Laws: An Exercise in Judicial Method, 2 RuT.-CAMr. L.J. 8 (1970). (1971)

43. See Sedler, Conflict of Laws: Round Table Symposium, 49 TEx. L. REv. 224

44. The conflicts field changes so rapidly that it is possible to refer to the "traditional interest analysis" developed by Professor Currie. See generally B. CuRRIE, stipra note 35. I differ with Professor Currie only in regard to distinguishing between "real" and "hypothetical" interests, and that difference will not frequently be significant. See Sedler, sispra note 43 , at 225 .

45. See Reese, supra note 10, at 692-93; cf. Currie, The Disinterested Third State, 28 LAW \& ConteMr. Prob. 754 (1963).

46. See B. Currie, stera note 35 , at 181-82.

47. Sedler, supra note 13 , at 41 . 
fairness. Despite protestations to the contrary, ${ }^{48}$ the basic concept underlying the Restatement denies to the courts a creative role in the development on a case-by-case basis of sound conflicts doctrine. The following observations, made previously in connection with the Second Restatement's approach to tort cases, are equally applicable to its treatment of contracts questions:

As with the original Restatement, it represents an externallyestablished system for the solution of all conflicts problems. It is granted that the rules of the Restatement Second are more flexible and in some respects seem to carry policy overtones. It is also granted that in deciding to prefer the Restatement Second over the original Restatement, courts may stress some policy considerations. Nonetheless, the approach is still one of a complete system of rules designed to solve all cases of a particular category. ${ }^{49}$

Therefore, while the rules of the Restatement Second may be more flexible (and more complex) and permit some consideration of policy, the system, nonetheless, is one of rules. ${ }^{50}$ Courts should "leap the bridge" from the system of rules approach to the policy-centered approach rather than "cross the bridge" from the "few simple rules" of the original Restatement to the "many complex" rules of the Restatement Second. In doing so they should also return to the judicial method of decision and accept responsibility for the development of a body of conflicts law. ${ }^{51}$

In the contracts area the approach of "judicial method and the policycentered conflict of laws" must take into account both the possibility of reliance on the law of a particular state by the parties and the common policy of all states to protect the legitimate expectations of the parties in commercial and consensual transactions. Moreover, unlike most rules of substantive tort law, particular rules of substantive contract law may not in themselves represent any strong policy beyond the general one of enforcing contracts and protecting the parties' expectations. A contract rule, for example, that makes a contract by mail complete upon the posting of the acceptance by the offeree rather than upon its receipt by the offeror would seem to represent, not any strong government policy, but only an effort to let the parties know when such a contract is complete. In contrast, a rule prohibiting the charging of usurious rates of interest would appear to represent a very strong policy imposing limits on

48. Reese, supra note 10 , at $680-82,697-99$.

49. If, as Professor Ehrenzweig suggests, the rules are so broad that they can be used to support any result, then the SECOND RESTATEMENT can best be characterized as an approach of "no rules at all." See The Second Conflicts Restatement, stipra note 3, at $1241-42$.

50. This is particularly evident in subsection (3) of section 188 (when place of negotiation and place of performance are in the same state, the law of that state will usually be applied) and in the comments to the corresponding tort rule of section 145 (when injury occurred in a single, clearly ascertainable state and when the conduct that caused the injury also occurred there, that state's law will be applied to most issues concerning the tort). See RestatemenT (SECOND), Explanatory Notes $\S 145$, comment $e$, at 420 .

51. Sedler, supra note 13 , at $61-63$ (footnotes added). 
parties' "freedom to contract." The Statute of Frauds would come somewhere in between. Where a strong policy is not involved and there may have been reliance on the law of a particular state, the displacement of the forum's law may well be proper. Nontheless, a rule-no matter how broadly (or precisely) framed-cannot be a substitute for judicial consideration not only of all facets of the problem presented in a particular case but also of the policies and interests of the concerned states and the requirements of fairness to the parties. ${ }^{52}$ It is my belief that courts should make decisions in contract cases, as in all others, with reference to considerations of policy and fairness and that these decisions should be made on a case-by-case basis.

In the present article, I shall discuss the basic choice-of-law issues in contract cases, using the framework adopted by the Restatement: (1) the power of the parties to choose the applicable law; (2) determination of the applicable law in the absence of an effective choice; and (3) choice of law in claims of usury. In so doing I will analyze the Restatement's approach and relate it to my own view as to how the matters should be dealt with under a policy-centered approach to conflict of laws. ${ }^{53}$

\section{Express Chotce of LAW}

\section{A. Matters Within the Contractual Capacity of the Parties}

Tle Restatement distinguishes at the outset between matters that are within the contractual capacity of the parties and those that are not. As to the former, full party autonomy is recognized under section 187(1), which provides:

The law of the state chosen by the parties to govern their contractual rights and duties will be applied if the particular issue is one which the parties could have resolved by an explicit provision in their agreement directed to that issue. ${ }^{54}$

I agree fully with this view. When the parties say that the law of a particular state "governs" with respect to matters that they could have covered in the contract, they are merely incorporating by reference the provisions of that law into the terms of their agreement. The so-called express choice of law is merely a shorthand way of doing so, and its effect is the same as if the chosen state's statutes and judicial decisions on that point had been explicitly written in.

52. For a discussion of this question in regard to the law of property, see id. at 106.

53. Under section 1-105 of the Uniform Commercial Code the parties are given the power to choose the applicable law. In the absence of such choice, the forum is directed to apply its version of the code if the transaction "bears an appropriate relation" to the forum. As to what constitutes an "appropriate relation," see Skinner v. Tober Foreign Motors, Inc., 345 Mass. 429, 187 N.E.2d 669 (1963). As to choice of law under the Uniform Commercial Code, see generally R. WenvTrAuB, supra note 1, at 270-71, 280-81; Nordstrom \& Ramerman, The Uniform Commercial Code and the Choice of Law, 1969 DUKE L.J. 623.

54. RestateMENT (SECOND) \& 187(1). 
Suppose, for example, that the parties to a contract, in a clause setting forth the conditions excusing performance (such as "fire, flood, labor disputes, etc."), also include the phrase "or other circumstances beyond the control of the parties." A dispute arises as to whether non-performance due to unfavorable business conditions is a valid excuse. The parties could have covered this contingency in their contract, but they did not. However, they did provide that the contract was to be "governed" by Michigan law. Under Michigan "contract construction" law, the phrase "other circumstances beyond the control of the parties" is limited to the kinds of events specifically named in the main body of the clause, so that here it would not include unfavorable business conditions. By providing that Michigan law governs on this point, the parties have done no more than incorporate by reference that part of Michigan law that says, in effect, unfavorable business conditions are not included. ${ }^{55}$ In such a case, no genuine choice-of-law issue is presented, and, as the Restatement recognizes, there should be no limitation on the power of the parties to incorporate foreign law into their contract. ${ }^{56}$

The courts, in dealing with choice-of-law clauses, do not always distinguish between matters within the contractual capacity of the parties and matters beyond their capacity. Moreover, they sometimes treat choice of law as to issues within contractual capacity as though it involved a conflict of laws problem. A good example of this confusion is the "carriage by sea" case of Siegelman v. Cunard White Star, $L t d .^{57}$ An American on a journey from New York to France was injured while a passenger on a ship of British registry. The steamship ticket, which was considered to be a contract, ${ }^{58}$ contained a "built-in" statute of limitations barring the initiation of any suit for personal injuries more than one year from the date of injury. It also provided that "all questions arising on this contract shall be decided according to English law with reference to which this contract is made." One-year "built-in limitations" were valid under both American ${ }^{59}$ and English law. ${ }^{60}$ Suit was brought in New York after the one-year period had expired, but the plaintiff claimed that the company's agent had waived the limitation provision by assuring the plaintiff that suit would not be necessary. ${ }^{61}$ Under English law

55. See Buono Sales, Inc. v. Chrysler Motors Corp., 363 F.2d 43, 47 (3d Cir.), cert. denied, 385 U.S. 971 (1966).

56. See R. WEINTRAUB, supra note 1, at 293. This is somewhat analogous to the use of foreign law as datum to determine factual questions made necessary by the application of the forum's law. See generally Kay, Conflict of Laws: Foreign Law as Datum, 53 CALIF. L. REv. 47 (1965).

57. 221 F.2d 189 (2d Cir. 1955).

58. It was called a "contract ticket" and was $13 \times 11$ inches in size. See 221 F.2d at 190-91. The document is reproduced in full in id. at 208-10.

59. See 46 U.S.C. $\$ 183(b)(1970)$.

60. See 221 F.2d at 194.

61. Paragraph 11 of the contract provided that the agreement could not be altered except by a writing signed by the company's chief agent at the port of embarkation. In view of the approach that the court took, it was not necessary to decide whether that provision was valid under English law. Id. at 198. 
the conduct of the agent would not amount to a waiver, and it was assumed that American law was to the contrary. The court held that English law applied as the law chosen by the parties. Although treating the issue as one "involving the circumstances under which parties may be said to have partially rescinded their agreements or to be barred from enforcing them," the court surprisingly went on to say that it was "more closely akin to a question of validity." still allowed English law to govern, but rested its decision on the assumption that express choice of law was permitted even as to matters beyond the contractual capacity of the parties. Judge Frank dissented on the ground that it was uncertain whether the choice-of-law provision was intended to govern the "post-injury conduct" of Cunard's agent in offering a settlement $t^{63}$ and that, because of this ambiguity, the clause should be construed most narrowly against the party who had authored it. ${ }^{64} \mathrm{He}$ went on to contend in dictum that the express choice of law should be denied recognition on the further ground that the contract as a whole was one of adhesion, "a standardized or mass-production agreement, with one-sided control of its terms."or

It seems that both the majority and the dissent misunderstood what was involved. The contract could have specifically provided, "And no agent of the company by any act whatsoever shall have the power to waive the one-year period." By providing that English law governed on this issue, the parties were merely doing the same thing in a shorthand way. Therefore, it was not necessary for the majority to discuss express choice of law as to matters beyond the contractual capacity of the parties. ${ }^{00}$ The position taken by the dissent is no more satisfactory. So long as the courts continue to enforce adhesion contracts in other respects, there can be no justification for refusing to give effect to an incorporation by reference of this sort. ${ }^{07}$ There was no claim that the validity of the agreement as a whole was impaired. Neither was there any reason to believe that the selection of England as the state of governing law was itself unconscionable or oppressive. ${ }^{68}$ This being the case, the defendant cannot be faulted for its reliance upon English law to govern its conduct during the settlement negotiations.

An especially valuable contrast may be drawn between Siegelman and the case of Fricke $v$. Isbrandtsen $\mathrm{Co}^{.99}$ In the latter, a German national, who could not read English, purchased a ticket in Germany for a roundtrip to the United States. The ticket, written wholly in English, provided that American

62. Id. at 195 .

63. Id. at 201 .

64. Id. at 202 .

65. Id. at 204.

66. By doing so the court set a precedent, and the opinion is a casebook favorite See R. Cramton \& B. Currte, Conflict of Laws 150 (1968); W. Reese \& M. Rosenderg, Cases and Materials on the Confltct of Laws 612 (6th ed. 1971).

67. Cf. notes 83-90 infra and accompanying text.

68. See 221 F.2d at 195-96.

69. 151 F. Supp. 465 (S.D.N.Y. 1957). 
law was to govern and contained a one-year "built-in limitation." It was contended that such a provision would be invalid under German law. ${ }^{70}$ The court refused to recognize the choice-of-law provision on the ground that this was an adhesion contract and, since the plaintiff could not read English, she could not have intended to make an express choice of law. It distinguished Siegelman on this basis and indicated that, if the contract had been written in German and the plaintiff had understood its terms, she would have been bound by the choice-of-law provision. ${ }^{71}$ Here too, it is submitted, the court was in error. The matter in dispute went to the validity of the "built-in limitation," a matter analytically beyond the contractual capacity of the parties, and it is well-settled that the validity of contractual provisions limiting tort liability cannot be controlled by an express choice of law. ${ }^{72}$ If the contract in Siegelman had provided for ouly a six-month period in which suit could have been brought, there can be no doubt that the express choice of a law validating such a provision would not have been recognized. ${ }^{73}$ It is thus clear that the court in Fricke had no need to distinguish Siegelman on grounds of "adhesion" or "strong policy." As will be pointed out in subsequent discussion, ${ }^{74}$ the result in Fricke need not have turned upon the inability of the plaintiff to assent to a provision that she could not understand. Rather, the choice-of-law provision -insofar as it attempted to speak to the validity of a limitation on liabilityshould have been disregarded because the party's home state had an interest in implementing its strong policy of allowing tort recovery despite contractual provisions to the contrary. Siegelman, where the choice-of-law provision was addressed to a question wholly within the discretion of the parties, was a different matter entirely.

So long as the issue involves a matter within the contractual capacity of the parties, any attempt to resolve that issue by incorporating the law of a particular state by reference should be fully recognized. It should not matter that the contract itself was an adhesive one or even that one party could not read it-so long as we enforce adhesion contracts generally and so long as we do not require that a party be able to read a contract if he has objectively manifested his consent. ${ }^{75}$ Incorporation, by reference, of foreign law as to matters

70. The case arose on the defendant's motion for summary judgment made in reliance upon American law. Thus, the plaintiff's view with respect to the effect of German law was accepted as proven. Id. at 468 .

71. Id.

72. In Ocean Steam Navigation Co. v. Corcoran, 9 F.2d 724 (2d Cir. 1925), for example, American law, which invalidated a contractual provision requiring claims to be filed within three days of any accident, was applied in the case of an American passenger injured aboard a British vessel, notwithstanding an express choice of English law.

73. See The Kensington, 183 U.S. 263 (1902); A. EHRENzwEIG, supra note 4, at 534-35; cf. Pisacane v. Italia Societa per Azioni di Navigazione, 219 F. Supp. 424 (S.D.N.Y. 1963) ; Caruso v. Italian Line, 184 F. Supp. 862 (S.D.N.Y. 1960).

74. See notes $99-120$ infra and accompanying text.

75. See 1 S. Wintiston, Contracts \& 35 (3d ed. Jaeger 1957). But see Silvestri v. Italia Societa per Azioni di Navigazione, 388 F.2d 11 (2d Cir. 1968). 
within the contractual capacity of the parties does not involve a choice-of-law problem-a point that is reinforced by the provisions of section $187(1) .^{70}$

\section{B. Matters Beyond the Contractual Capacity of the Parties}

Under section $187(2)$ express choice of law is recognized "even if the particular issue is one which the parties could not have resolved by an explicit provision in their agreement." There are, however, three exceptions, when: (1) the chosen state has no substantial relationship to the parties or the transaction and there is no other reasonable basis for the parties' choice; ${ }^{77}$ (2) the consent of one of the parties to the inclusion of the provision was secured by misrepresentation, duress, undue influence or mistake $;^{78}$ or (3) application of the law chosen would be contrary to a fundamental policy of a state that has a materially greater interest than the chosen state in the determination of the particular issue and such other state would, in the absence of an effective choice, be the state of the most significant relationship under section $188 .{ }^{70}$

The justification for permitting choice of law as to matters beyond the contractual capacity of the parties has been stated by the drafters of the Restatement (Second) as follows:

Prime objectives of contract law are to protect the justified expectations of the parties and to make it possible for them to foretell with accuracy what will be their rights and liabilities under the contract. These objectives may best be attained in multistate transactions by letting the parties choose the law to govern the validity of the contract and the rights created thereby. In this way, certainty and predictability of result are most likely to be secured. Giving parties this power of choice is also consistent with the fact that, in contrast to other areas of the law, persons are free within broad limits to determine the nature of their contractual obligations. ${ }^{80}$

It is difficult to dispute the contention that permitting the parties expressly to choose the governing law serves these objectives, although, as Professor Weintraub contends, they would be better served by validating the contract "whenever it is reasonable to do so irrespective of whether or not the parties have made an express choice of validating law." 81

1. Reasonableness Requirement. In any event, the crucial question is what limitations will be placed upon the power of the parties to choose the

76. See Restatement (Second), Explanatory Notes $\S 187$, comment $c$, at 563-64.

77. Id. \& $187(2)$ (a).

78. This exception is included in the comments rather than in the text. See RestateMENT (SECOND), Explanatory Notes \& 187, comment $b$, at 562. An earlier draft included it in the text. Id. \& 332a (Tent. Draft No. 6, 1960).

79. RESTATEMENT (SECOND) \& $187(2)(\mathrm{b})$. It is stated that the exceptions do not apply "when all contacts are located in a single state and when, as a consequence, there is only one interested state." Id., Explanatory Notes $\$ 187$, comment $d$, at 564 .

80. RESTATEMENT (SECOND) \& 187, cominent $e$, at 565. It is now recognized that allowing the parties to choose the applicable law does not give them the power to "legislate" since their "power" to choose the law is given by the forum's choice-of-law rule. See Reese, supra note 11 , at 534.

81. R. WeINTRAUB, supra note 1 , at $271,273-74$. 
applicable law. The first limitation that the Restatement imposes-that the state whose law is chosen have a substantial relationship to the contract, or otherwise be reasonable-is not, as the drafters' comments point out, a significant one. They note that such a situation will not arise in practice, since "[c]ontracts are entered into for serious purposes and rarely, if ever, will the parties choose a law without good reason for doing so."82

2. Misrepresentation, Duress, Undue Influence or Mistake. The second limitation, going to mistake, duress and the like, raises two important questions: (1) Shotuld the choice of law be recognized if the contract is one of adhesion? (2) Should the choice of law be recognized if it would invalidate the contract or a part thereof?

(A.) Choice of Law Dictated by Superior Bargaining Power. With respect to choice-of-law provisions contained in adhesion contracts, it is important to distingtuisl the situation presented in a case such as Fricke from the "ordinary adhesion" case. In the more usual situation, although the adherent could have read the contract, it would not have mattered since the document was a standardized form agreement and there could not have been any real bargaining or negotiation about its terms. ${ }^{83}$ In Fricke, the inability of the adherent to read the contract would negative any "intention" on her part to "choose governing law." In the ordinary case, however, such an intent could be inferred. Since adhesion agreenents are generally enforced in other respects, it could be argued that choice-of-law stipulations sliould be treated no differently. The Restatement takes a very guarded position here, observing that choice of law provisions contained in adhesion contracts ${ }^{84}$ are usually respected, but that, " $[n]$ evertheless, the forum will scrutinize such contracts witl care and will refuse to apply any clioice-of-law provision they may contain if to do so would result in substantial injustice to the adherent." 85 And courts liave been willing to enforce such clioice-of-law stipulations, at least where the adhesive nature of the contract was due to the absence of negotiations rather than to "unconscionability." Professor Ehrenzweig, on the other hand, contends that the principle of party autonomy has no place in the conflicts law of standardized contracts, since "the adherent, "having no real choice about the

82. Restatenent (Second), Explanatory Notes $\S 187$, comment $f$, at 566-67. But see Owens v. Hagenbeck-Wallace Shows Co., 58 R.I. 162, 192 A. 158 (1937) (the court refused to uphold a choice of Florida law in a contract between a circus and a circus performer on the ground that the contract had no physical connection with Florida. Since many circuses make their winter headquarters in Florida, Florida law was a reasonable one for the parties to choose); $c f$. A. EHRENzWEIG, supra note 4 , at 528. Of course, if such a situation never arises in practice, it may be asked why it was necessary to include a "rule" governing it.

83. Standardization may or may not reflect inequality of bargaining power. Insurance contracts are standardized, often as a result of state regulation. Insurance sales are nevertheless frequently made in a "Buyer's market." The same may be true of lcasing arrangements, where the contracts also are usually standardized.

84. It does not distinguish between standardization and inequality of bargaining power.

85. REsTATEMENT (SECOND), Explanatory Notes $\$ 187$, comment $b$, at 562 .

86. See, e.g., Boase v. Lee Rubber \& Tire Corp., 437 F.2d 527, 530-31 (3d Cir. 1970). 
matter, cannot in fairness be said to have joined in a "choice of law" '."Br Professor Cavers, in contrast, agrees with the Restatement's approach, observing that choice-of-law provisions "have a value in the planning and conduct of a business operating over a broad spectrum of states, a value independent of the existence of a peculiarly favorable constellation of laws in the state chosen," so that, " $[e] x$ xcept where the provision would be harsh on the other party, a court might well accept a choice made by adhesion."

My position as to whether an adhesive choice of law should be recognized cannot be separated from my view that, as to all matters beyond the parties' contractual capacity, choice of law should be allowed only when the matter at issue does not involve the strong policy of any of the concerned states. ${ }^{80}$ If express choice of law is so limited, I see no real objection to allowing the express choice to operate against adherents. So long as we enforce adhesion contracts generally, we may as well be consistent, even as to express choice of law..${ }^{90}$ However, in the limited circumstances in which I would recognize an express choice of law, enforcing those provisions against adherents is unlikely either to work "substantial injustice" or to deprive them of important protections to which they are entitled under the law of their home state.

(B.) Choice of a Law that Invalidates the Agreement. I would also contend that an otherwise proper express choice of law should be recognized even if it would invalidate the contract or a part thereof. The Restatement blithely states that if the parties have chosen a law that would invalidate the contract, it can be assumed that they did so by mistake. ${ }^{01}$ Professor Weintraub agrees that a stipulation of invalidating law can be disregarded as an "obvious error." ${ }^{22}$ But is this really so? Consider a case such as A.S. Rampell, Inc. v. Hyster $\mathrm{Co}_{0}{ }^{93}$ in which, according to Professor Weintraub, the "law chosen by the parties invalidated a provision in the contract." corporation doing business in New York; Rampell was a distributor of Hyster's products in parts of New York and New Jersey. The dealermanufacturer relationship had existed for a number of years under written contracts permitting either party to terminate at any time. Each of these contracts contained a provision to the effect that the contract was to be

87. A. EHRENZWEIG, supra note 4 at 456-57, quoting from Siegelman v. Cunard White Star, Ltd., 222 F.2d 189, 206 (2d Cir. 1955) (Frank, J., dissenting). He contends that in practice the stipulations will be upheld only where they have protected the adherent or where, despite the standardized form, there was equality of bargaining power. See also Nordstrom \& Ramerman, supra note 53, at 630-31; R. WernTRAUB, supra note 1 , at 274 .

88. CAVERS, supra note 39 , at 360.

89. See notes 100-21 infra and accompanying text.

90. Professor Ehrenzweig, to the contrary, contends that courts should use the conflicts case to set an example. A. EHRENzweig, silpra note 4, at 457-58.

91. RESTATEMENT (SECOND), Explanatory Notes \& 187, comment $e$, at 566.

92. R. WeINTRAUB, supra note 1 , at 273 .

93. 3 N.Y.2d 369, 144 N.E.2d 371, 165 N.Y.S.2d 475 (1957).

94. R. WEINTRAUB, supra note 1 , at 272 . 
governed by Oregon law. When Hyster terminated the agreement, Rampell sued in New York, claiming that subsequent to the execution of the last contract, Hyster had orally agreed that it would not terminate the distributorship except "upon just cause and reasonable notice." Hyster contended that the alleged oral modification was ineffectual because it violated the New YYork Statute of Frauds. The court rejected this defense, applying Oregon law (under which subsequent oral modifications were valid) as the law chosen by the parties. While application of the chosen law, in effect, invalidated a portion of the written agreement by rendering it inoperative, it upheld the oral modification. To that extent the court "gave effect to the expectations of the parties." Clearly the parties intended to choose Oregon law to govern the contract. Indeed, it can be argued that when they entered into the oral modification, they relied on Oregon law to uphold the oral modification as valid. In any event, their choice of law can hardly be termed an "obvious error."

Now consider a case such as General Electric Credit Corp. v. Beyerlein, ${ }^{95}$ in which the court applied the law chosen by the parties to invalidate a clause cutting off the buyer's defenses against an assignee of the seller. The seller may have made a mistake, but it does not at all follow that the buyer also did. In fact, he may have agreed to the choice-of-law clause or even demanded its insertion precisely because he knew that it would render unenforceable the provision insulating the assignee. The assumption that parties always intend to be fully bound by a contract into which they have entered is naive. Each may want the other to be bound but may hope that he can escape obligations if he finds it advantageous to do so. Here the buyer, by agreeing to the express choice of law, may have intended to put himself in the position of having a perfectly good contract that he could enforce against the seller but that could not be enforced against him by the seller's assignee unless the assignee also assumed the seller's obligations. Perhaps it was "unjust" for him to take advantage of the seller in this way, if this is what actually occurred; but it certainly cannot be assumed that the parties made a mutual mistake when they chose the applicable law.

The absence of mutual mistake becomes even clearer when the choice-oflaw provision contained in an adhesion contract serves to benefit the adherent. In Pisacane v. Italia Societa Per Azioni Di Navigazione, ${ }^{96}$ an Italian shipping line inserted a provision to the effect that all actions for personal injuries had to be brought within a year from the date of the accident and another provision that Italian law governed. The only problem was that under Italian law it appeared that the built-in limitation period was void. ${ }^{97}$ In Jones $v$. Tindall, ${ }_{9}^{98}$

95. 55 Misc. 2d 724, 286 N.Y.S.2d 351 (Sup. Ct. 1967).

96. 219 F. Supp. 424 (S.D.N.Y. 1963).

97. Under Italian law it appeared that the period had to run from the time the passenger arrived at his destination. The case came up on a motion for summary judgment. See also Caruso v. Italian Line, 184 F. Supp. 862 (S.D.N.Y. 1960). (In 
the Tennessee lender inserted a choice-of-law provision applying the law of Arkansas, the residence of the borrower, and lo and behold, the interest rate was usurious under Arkansas law. In both of these cases, the dominant party did indeed make a mistake, but since the other party did not participate in the choice of law, it is absurd to speak of mutual mistake. Moreover, it certainly seems fair to give the dominant party the "fruits of his choice," however tart these may prove to be.

If in a given case it can be shown that the parties actually made a mutual mistake-as evidenced, for example, by a choice of law that would nullify the entire agreement, and that was truly contrary to both parties' intentions-there is justification for ignoring the express choice. But otherwise, it should be assumed that the parties intended to do what they did and to accept the consequences of their decision. ${ }^{99}$

3. Conflicting Governmental Policy. We now come to the Restatement's third and most important limitation: The choice of law will not be recognized when the "application of the law of the chosen state would be contrary to a fundamental policy of a state which has a materially greater interest than the chosen state in the ... particular issue and which, ... in the absence of an effective choice," would be the state of the most significant relationship. ${ }^{100}$ The very words used in formulating the limitation indicate an intention to circumscribe it as much as possible. It is not enough that the policy be a strong one; it must be "fundamental." It is not enough that the state whose law would otherwise govern under the Restatement's approach have some interest or even a strong interest in applying its own law; that interest must be "materially greater" than the interest of the chosen state. Finally, the other state must also be the state of the most significant relationship. The burden here would appear to be a formidable one indeed.

The working model on which the Second Restatement proceeds assumes that all cases are heard in a distinterested forum. With respect to section 187, such a forum must decide whether the "fundamental policy" of the state of the most significant relationship is to be preferred over the law of the state chosen by the parties. In practice, however, despite our law of transient jurisdiction, the grcat majority of cases will be brought in an interested forum. Based on this interest, the forum can constitutionally apply its own law if it so chooses. ${ }^{101}$ When the issue in question involves a strong, albeit not "fundamental policy" of the forum, and when the forum has an interest in applying its own law to

a similar factual situation the court applied Italian law "on the merits," refusing to recognize the express choice of law provision to that effect.)

98. 216 Ark. 431, 226 S.W.2d 44 (1950).

99. See the very effective discussion with reference to the English practice in A. DiceY \& J. MORRIS, THE CONFLICT OF LAws 708 (8th ed. 1967).

100. Restatement (SECOND) \& 187 (2) (b).

101. The application of its law must, however, be fair to the other party, and it generally will be. See Clay v. Sun Ins. Office, Ltd., 377 U.S. 179 (1964); cf. Home Ins, Co. v. Dick, 281 U.S. 397 (1930). 
implement that policy, it may be asked whether the forum will displace its law merely because the parties have expressly chosen the law of another state. I would submit that the forum ordinarily will not do so and that the significant considerations affecting its decision are whether it regards the policy represented by its law to be sufficiently strong to warrant its application in such a case and whether the application of the forum's law would be unfair to either party. In this connection, the fact that the choice of law was secured pursuant to an adhesion contract may be relevant when the adherent is a forum resident who has entered into the agreement in a jurisdiction whose laws accord him less protection than those of the forum. By the same token, even if the forum has no real interest in the application of its own law, ${ }^{102}$ it is likely to treat the choice of law expressed in the agreement from the perspective of a state whiose interests are affected by the issues at bar..$^{103}$

We may illustrate this point by considering a variety of situations in which choice-of-law provisions interact with strong policies of a concerned state-not necessarily the forum in which suit is brought. In the case of carriage-by-sea contracts, we have already noted that courts in general will not recognize an express choice of law that has the effect of barring tort recovery where an explicit contractual limitation on liability would be invalid under the law of the victim's home state. ${ }^{104}$ This works both ways. If the victim is a resident of the forum, the forum will apply its own law in disregard of any contract provision specifying the law of another state. ${ }^{105}$ Even if the agreement calls for the application of the forum's own law, a forum whose interests are not significantly affected may still defer to the law of the victim's state of residence. ${ }^{106}$ Similar results obtain in the instance of life insurance contracts. As to this class of agreements, the Restatement concludes that the insured's domicile is the state with the most significant relationship to the contract ${ }^{107}$ and that effect will frequently not be given to a choice-of-law provision that looks to another state, since "[1] ife insurance is a natter of intense public concern, ... . [and] a major purpose of . . . legislation [in this area] is to protect the individual insured ..." 108 The rationale behind this rule is that to give the insured less protection than would be extended under the law of his domicile would in all probability "be repugnant to a fundamental policy of the state" having the most significant relationship to the insurance contract. ${ }^{109}$

102. It might be a purely disinterested forum or it may conclude after a careful analysis of policies and interests, that it lacks any real interest.

103. An analogous practice has been employed in tort cases. See, e.g., Tramontana v. S.A. Impressa de Viacao Aerea Rio Grandense, 350 F.2d 468 (D.C. Cir. 1965); Long v. Pan Ameriean World Airways, 16 N.Y.2d 337, 213 N.E.2d 796, 266 N.Y.S.2d 513 (1965). 104. See notes 69-73 supra and accompanying text.

105. See Oceanic Steam Navigation Co. v. Corcoran, 9 F.2d 724 (2d Cir. 1925).

106. See Fricke v. Isbrandtsen Co., 151 F. Supp. 465 (S.D.N.Y. 1957).

107. RESTATEMENT (SECOND) \& 192.

108. Id., Explanatory Notes $\$ 192$, comment $c$, at 602 . The Restatement also emphasizes the adhesive nature of insurance contracts.

109. Id., comment $e$, at 604 . 
There can be no doubt that the courts of the insured's domicile would agree.110 In the case of property insurance, the Restatement takes a similar position, noting that the state of the insured's domicile would not recognize an express choice-of-law provision displacing its law as to a contract insuring property situated within the state.111 What, it may be asked, makes the policy of protecting insureds a "fundamental" one under the rubric of section $187(2)$ (b) ? In my view, the answer is obvious. The domicile has a clear interest in applying that policy for the benefit of its residents and in regnlating the conduct of companies that insure its residents or their property. This becomes particularly evident when we consider an agreement to insure property located outside the forum. In that situation, the interests of the forum in regulating insurance companies are much less clear, and the application of its law might be unfair to the insurer. An express choice of law should therefore be recognized.112 Analogous considerations apply in all instances where contractual provisions trench upon strong policies of the forum. Thus, the forum will not recognize the parties' choice of law to determine the validity of a covenant not to compete where the competition takes place in the forum and where, under its laws, such agreements are regarded as being in restraint of trade. ${ }^{113}$

These examples demonstrate that whether the forum will give effect to an express choice of law displacing its own depends upon whether the issue involves a strong policy of the forum and whether the forum has an interest in applying its law to implement that policy in the particular case. Certain questions analytically going to validity, such as the existence of consideration, do not involve a strong policy..$^{114}$ Here the forum would recognize an express choice of law. ${ }^{115}$ Other matters, such as serious illegality, just as obviously do involve a strong policy. ${ }^{110}$ There is no doubt, as the Restatement itself recognizes, ${ }^{117}$ that an express choice-of-law provision cannot be employed to defeat the policy of the forum or another interested state.

110. See Zogg v. Penn Mut. Life Ins. Co., 276 F.2d 861, 863-65 (2d Cir. 1960) (importance of insured's domicile applying its law to protect him). Although that case did not involve express choice of law, the lower court's rationale would clearly serve to invalidate any such choice.

111. RESTATEMENT (SECOND), Explanatory Notes \& 193, comment $e$, at 613.

112. See id.; Home Ins. Co. v. Dick, 281 U.S. 397 (1930); Quarty v. Insurance Co. of North America, 244 So. 2d 181 (Fla. App. 1971).

113. See, e.g., Forney Industries, Inc. v. Andre, 246 F. Supp. 333 (D.N.D. 1965).

114. See A. EHRENZWEIG, supra note 4, at 479-80. It is significant that the Uniform Commercial Code does not require consideration in the case of firm offers between merchants. See Uniform Commercial Code $\$ 2-205$.

115. See RESTATEMENT (SECOND) \& 187, comment $e$, illus. 8 , at 566; cf. Pritchard v. Norton, 106 U.S. 124 (1882).

116. I believe that the Statute of Frauds, contrary to the assertion of the Restatcment, see $\$ 187$, comment $g$, at 568 , also involves a strong policy, representing as it does a legislative determination that certain kinds of agreements should not be enforced unless the parties manifest their seriousness by giving the contract the required degree of permanency. See International Planning, Ltd. v. Daystrom, Inc., 24 N.Y.2d 372, 382-83, 248 N.E.2d 576, 582-83, 300 N.Y.S.2d 817, 826-27 (1969). The policy considerations applicable to Statute of Frauds questions are discussed more fully in notes $156-63$ infra and ac-
companying text.

117. Restatenient (Second), Explanatory Notes $\S 187$, comment $g$, at 568 . 
Even though the forum law in question may represent a strong policy, the forum will not refuse recognition to the express choice of law unless it has a real interest in applying its law to implement the policy in the particular case. In A.S. Rampell, Inc. v. Hyster Co., ${ }^{118}$ for example, New York did not see itself as having any real interest in applying its Statute of Frauds to protect an Oregon corporation against a New York corporation in a dispute involving a distributorship agreement. ${ }^{110}$ Suppose, however, that the contract had provided that there was to be no termination except for cause and Hyster claimed that a subsequent oral modification gave it the right to terminate at will. New York might then view differently its interest in applying its law to regulate the transaction and, in this case, protect the New York distributor. If so, it might not recognize the express choice of law. ${ }^{120}$

In practice, it will not ordinarily be possible to discover cases in which the forum, despite a real interest in applying its own law, displaces its law in response to an express choice-of-law provision. Indeed, the forum should allow such displacement only when the matter at issue does not involve a strong policy of the forum or when the forum has no real interest in applying its law to implement that policy because of the particular circumstances of the case. Conversely, when the parties expressly choose the law of the forum, but the forum has no real interest in applying its law and another state does have a strong policy interest, the choice of law should be denied recognition, and the law of the interested state should be applied.121

Let me sum up my approach to contractual choice-of-law provisions as follows: An express choice of law should be fully recoguized as to matters within the contractual capacity of the parties, because the parties are merely incorporating the foreign law by reference and no choice-of-law issue is really presented. An express choice of law should also be recognized as to matters analytically beyond the capacity of the parties so long as these matters do not involve a strong policy of the forum or another concerned state. An express choice of law that would otherwise be recognized should not be denied effect on grounds of "mistake" simply because the law chosen will invalidate the contract or a part thereof. Likewise, it should not be refused recognition because of its adhesive nature, unless in the particular circumstances the adherent could not be considered in any way to have made a choice of law..$^{122}$

My approach agrees with the Restatement's only as to matters within the

118. 3 N.Y.2d 369, 144 N.E.2d 371, 165 N.Y.S.2d 475 (1957).

119. Compare id. with International Planning, Ltd. v. Daystrom, Inc., 24 N.Y.2d 372, 248 N.E.2d 576, 300 N.Y.S.2d 817 (1969). See notes 156-63 infra and accompanying text.

120. The problem of an express choice of law and the Statute of Frauds could arise only in a case such as Rampell in which there was a written agreement containing a choice-of-law clause and an alleged subsequent oral modification.

121. A disinterested third state should likewise apply the law of the interested state, irrespective of the express choice of law.

122. This would be limited to a case such as Fricke v. Isbrandtsen Co., $151 \mathrm{~F}$. Supp. 465 (S.D.N.Y. 1967). See notes 69-73 supra and accompanying text. 
contractual capacity of the parties. I take a much more restrictive view as to matters beyond their contractual capacity and would limit the effect of an express choice to those issues that do not involve a strong policy of the forum or of another concerned state. It is submitted, moreover, that this approach is more in line with the actual practice of courts and provides a proper accommodation between the objective of protecting the legitimate expectations of the parties and that of giving effect to the interests of the states concerned in implementing the important policies reflected in their laws.

\section{Applicable Law in the Absence of an Effective Chotce}

\section{A. The State of the Most Significant Relationship: Localization and Implied Intent}

Where the parties have not made an effective choice of law, section 188 of the Restatement provides that, "[t] he rights and duties of the parties with respect to an issue in contract are determined by the law of the state which, with respect to that issue, has the most significant relationship to the transaction and the parties."123 The state-of-the-most-significant-relationship test is applicable to all matters-matters within the contractual capacity of the parties, matters that do not involve a strong policy, and matters that do involve a strong policy of the forum or another state. ${ }^{124}$ In conception, it is a localizing rule based on factual contacts. While policies are relevant in assessing the importance of these contacts, and while the choice of law may depend upon the particular issue involved, nonetheless, the Restatement's basic premise is that an agreement must be "most significantly related". to a particular state, and this relationship can only be determined with reference to factual contacts. As the drafters point out:

Frequently, it will be possible to decide a question of choice of law in contract without paying deliberate attention to the purpose sought to be achieved by the relevant contract rules of the interested states. This will be so whenever by reason of the particular circumstances one state is obviously that of the applicable law. ${ }^{125}$

Moreover, it is expressly provided that if the place of negotiation and the place of performance are the same, that state will usually be the state of the most significant relationship..$^{126}$

This form of approach does pose a fairly basic problem. Where a rule is framed in terms of factual contacts, it is all too easy for whatever policy considerations it embodies to be subordinated in the effort to localize the

123. Restatennent (SECOND) § 188(1).

124. The only exception is for the details of performance RESTATEMENT (SECOND) \$ 206. See id., Explanatory Notes \& 188, comment $e$, at 580 .

125. Id., Explanatory Notes $\$ 188$, comment $c$, at 578-79.

126. $I d$. $\S 188(3)$. See note 17 supra and accompanying text. 
transaction in a particular state. ${ }^{127}$ Although the Restatement admonishes that " $[t]$ hese contacts are to be evaluated according to their relative importance with respect to the particular issue," 128 there is, as Professor Weintraub warns:

grave danger that section 188 will be interpreted to direct the counting of physical contacts with the parties and with the transaction and the awarding of the palm to the state with the "most" contacts. To the judge or lawyer, not expert in conflicts theory and working under time pressures that prevent scrutiny of the Second Restatement in all its detailed commentary on the black letter, this counting seems invited by section one eighty-eight's listing of contacts "to be taken into account." It is the complete antithesis of functional analysis to list any contact as "significant," a priori, without first knowing the domestic law of the state having that contact and the policies underlying that domestic law. ${ }^{129}$

In discussing express choice of law, I drew a distinction between two classes of issues that might arise during the litigation of an action in contract. The first of these included both matters within the contractual capacity of the parties and those that, while analytically beyond their capacity, do not interact with any strong governmental policy. The second class was comprised of those issues that do involve a strong policy either of the forum or of another interested state. Since the question of the applicable law in the absence of an effective choice by the parties involves parallel considerations, the analysis that follows, particularly as it deals with the "state of the most significant relationship" concept, will be made with reference to that same distinction.

As to the first category-where I favor party autonomy-"the state of the most significant relationship" approach may have utility if it is viewed as employing the methodology of localization to try to determine the implied intent of the parties. Where it is possible to localize the contract in such a way that it can be said that the parties did intend or would have intended, if they had thought about it, that the law of a particular state apply, I think it makes sense to look to the law of that state to determine matters that lie within the contractual capacity of the parties and matters that do not involve any strong policy. ${ }^{130}$ The justification is exactly the same as that for recognizing an express choice of law: to give effect to the expectations of the parties. Here an argument can also be made in favor of finding validity whenever

127. To me, the "horror case" illustrating this point in the tort context is Dym $\nabla$. Gordon, 16 N.Y.2d 120, 209 N.E.2d 792, 262 N.Y.S.2d 463 (1965). Dym was effectively overruled in Tooker v. Lopez, 24 N.Y.2d 569, 249 N.E.2d 394, 301 N.Y.S.2d 519 (1969).

128. Restatemient (SECOND) \& 188(2).

129. R. WEINTRAUB, supra note 1 , at $276-77$.

130. Professor Reese has analogized the state of the most significant relationship approach to the English "proper law of the contract" doctrime, see Reese, supra note 11, at 537, which looks to the "system of law by which the parties intended the contract to be governed, or, where their intention is neither expressed nor to be inferred from the circumstances, the system of law with which the transaction has its closest and most real connection." DiceY \& MoRrIs, supra note 99, at 561. The "proper law" doctrine thus combines express and implied intent in a localizing rule. 
possible, since, unlike the express-choice-of-law situation, there would be nothing to indicate that one or both of the parties made the choice in the hope of subsequently being able to rely on the law of a particular state to invalidate the contract or a part of it. ${ }^{131}$

The "localizing-implied intent" concept is well-illustrated by the "classic" English case of Jacobs, Marcus \& Co. v. The Credit Lyonnais. ${ }^{132}$ Two English businessmen entered into a contract in England for the collection of goods in Algeria and their transport back to England on the plaintiff's ships. Payment was to be made in England. Due to an insurrection in Algeria, the defendant was unable to deliver. Insurrection constituted the defense of impossibility under Algerian law but not under British law. In a suit on the contract in England, local law was applied as the law intended by the parties. Whether the obligation was excused by impossibility was a matter within the contractual capacity of the parties. It cannot be doubted that two English businessmen, contracting in England for the shipment of goods there, intended that English law rather than the "barbaric law" of a foreign country govern their relationship. As the drafters observe in commenting on this case,

[t] hat $A$ and $B$ are both domiciled in $X \ldots$, that the contract was negotiated and executed in $X$ and that delivery of the commodity was to be made in $X$ are factors which should lead the $Z$ court $^{138}$ to the conclusion that $X$ is the state of dominant interest, and that accordingly $X$ local law should be applied. ${ }^{134}$

Where both parties have their principal place of business in the same state and the contract involves their business activities there, it is reasonable to assume that they expected or would have expected the law of that state to apply.

Another example is the "modern classic" case of Auten v. Auten, ${ }^{135}$ which applied the state-of-the-most-significant-relationship test of the Restatement (Second), although, as I have maintained elsewhere, this case did not really involve a "contract" problem. ${ }^{136}$ The parties were English domiciliaries; the case involved a support agreement; and England was the marital domicile. Payment was to be made to a New York trustee, who was to remit the money to England. The only reason the contract was made in New York was that the wife "caught up with" the husband there. The New York court talked about England's interest in regulating the contract, but also emphasized that the parties could not "have expected or believed that any law other than England's would govern the effect of the wife's institution of a separation

131. See notes 91-99 supra and accompanying text.

132. 12 Q.B.D. 589 (C.A. 1884).

133. The likelihood of such a case arising in a disinterested third state is nil.

134. RESTATEMENT (SECOND), Explanatory Notes $\S 205$, comment $c$, illus, 1 , at 663 (footnote added).

135, 308 N.Y. 155, 124 N.E.2d 99 (1954).

136. See Sedler, Characterization, supra note 42, at 86-88. See also Haag v. Barncs, 9 N.Y.2d 554, 175 N.E.2d 441, 216 N.Y.S.2d 65 (1961). 
action. ${ }^{137}$ The matter in issue-whether the institution of a separation action abrogated the contract-was again one that could have been dealt with by the parties in their agreement.

When the factual contacts are more divided, a finding in favor of validity may properly tip the balance in determining the law "the parties intended or should have intended." This is illustrated by still another "classic case," Pritchard v. Norton, ${ }^{138}$ which involved litigation over a contract of indemnity entered into in New York by New York and Delaware defendants and a Louisiana plaintiff. The contract was designed to cover the plaintiff's liability as surety of an appeal bond that he executed on behalf of a railroad against which a Louisiana trial court had entered a judgment. The railroad's appeal was unsuccessful, and the surety was required to pay. The defense to his suit against the indemnitors was that the agreement lacked consideration under New York law. Consideration, while analytically going to validity, cannot be said to involve any strong policy. ${ }^{139}$ In denying the defense, the Court tried to localize the contract in Louisiana, emphasizing that it was there that the acts giving rise to the indemnitor's duty had occurred, and it buttressed its conclusion with the argument that "the parties cannot be presumed to have contemplated a law which would defeat their engagements."140

In the event that the factual contacts are so divided among various states that it is not possible to localize the contract or any part of it in a given state-a possibility that the Restatement does not seem to recognize ${ }^{141}$-an alternative solution is necessary. When the issue of validity does not trench upon a strong policy, an argument can be made, as in Pritchard, for applying the law that would validate the contract. Of course, as to matters purely within the contractual capacity of the parties, the law of the forum (as the basic law) should always be applied in default of any reason for its displacement. ${ }^{142}$

What I have proposed, therefore, with respect to matters within the contractual capacity of the parties and matters not involving a strong policy, combines the Restatement's express choice-of-law provisions and its state-ofthe-most-significant-relationship approach. When an express choice has not been made, the localizing concept of the "state of the most significant relationship" would be employed to identify implied intent, and implied intent would

137. Auten v. Auten, 308 N.Y. 155, 163, 124 N.E.2d 99, 103 (1954). Since the wife was returning to England, it would have known that any action she might take would have had to have been taken there.

138. 106 U.S. 124 (1882).

139. See note 114 supra and accompanying text.

140. 106 U.S. 124, 137.

141. The assumption is that the disinterested forum will somehow always be able to discover a state that, "with respect to the transaction and the parties," is the state of the most significant relationship.

142. If the action is brought in a purely disinterested third state, the court should probably look to the law of the "interested state" that most nearly resembled its own. 
be used to determine those matters that otherwise could have been determined by a manifestation of express intent.

\section{B. Localization versus Policy}

Most cases, however, do not involve differing laws as to matters within the contractual capacity of the parties or matters not involving a strong policy of the forum or other concerned state. Instead they raise questions of the Statute of Frauds, ${ }^{143}$ the capacity of certain parties to enter into contracts, the enforceability of particular kinds of contractual obligations, or the validity of specific defenses. In general they present the conflict between a policy of one state, which allows an agreement to be enforced, and a policy of another state, which protects a party from contractual liability. Under the Restatement approach, the localizing concept of the "state of the most significant relationship" is equally applicable to these cases. Although presumably policy considerations would be more important here, the emphasis is still on localization. There is, I would submit, a very important difference between dealing with such problems in terms of considerations of policy and fairness and trying to solve them simply by the application of a localizing rule.

The difference can be illustrated by an analysis of the much-criticized decision in Lilienthal $v$. Kanfman. ${ }^{144}$ An Oregon borrower secured a loan in California from a local resident. When the borrower defaulted, the lender discovered that prior to the transaction the borrower had been declared a spendthrift in Oregon and had been placed under gnardianship. Under Oregon law the guardian could avoid the contracts of the spendthrift other than those for necessaries, and in this case the guardian refused to pay the note. Upon bringing suit in Oregon, the borrower was met with the defense of spendthrift immunity, which the Oregon court had earlier sustained in a purely domestic case involving the same defendant. ${ }^{145}$ In Lilienthal the defense was sustained against the foreign lender as well.

The court stated that California law "governed" the contract as the law of the state of the most significant relationship, since the borrower had approached the lender in California to ask for the loan, the money had been loaned to him there, and by the terms of the note it was to be repaid there. The court also cited the provision of section 188(3) to the effect that if the place of negotiation and the place of performance are in the same state, that state is generally the state of the most significant relationship. ${ }^{146}$ It went on to hold, however, that to apply California law would be against Oregon's "public policy" and that the public policy of the forum was "so strong that the law of

143. As to the responsibility of the courts to implement the legislative policy with respect to the Statute of Frauds, see the discussion in Currie, supra note 9, at 245-50. 144. 239 Ore. 1, 395 P.2d 543 (1964). See note 214 infra and accompanying text. 145. Olshen v. Kaufman, 235 Ore. 423, 385 P.2d 161 (1963).

146. The same provision was contained in section $332 \mathrm{~b}(\mathrm{a})$ of the $1960 \mathrm{draft}$, to which the court in Lilienthal referred. 
the forum must prevail although another jurisdiction, with different laws, has more and closer contacts with the transaction."147

In justifying the result, the court explicitly applied Professor Currie's interest-analysis approach. ${ }^{148}$ It saw California's interest as assuring that its creditor be paid and upholding its reputation as a state where contracts could be made with certain knowledge that they would be enforced.

Oregon's interest was in protecting the spendthrift and his family-what I have called an anti-contractual policy ${ }^{149}$-and the Oregon legislature had determined that the policy of protecting the spendthrifts was more important than the policy of enforcing contracts. Although Oregon also had an interest in encouraging residents of other states to conduct business with Oregon residents, this interest, in the words of the court, "was deflated by the recollection that the Oregon Legislature lias determined, despite tlie weight of these considerations, that a spendthrift's contracts are voidable."150 In other words, the policy to be implemented by the spendthrift statute was no different in the foreign case from what it was in the domestic one, and the court recognized the legislative determination in botll cases. It resolved the true conflict ${ }^{151}$ in what Professor Currie contends is the only manner in which such a conflict can rationally be resolved-by the application of the forum's law. ${ }^{152}$ In contrast, under the state-of-the-most-significant-relationship approacl espoused by the Second Restatement, California law would have to govern in this case; the conflicting interests would be resolved with reference to the factual contacts that the contract had with the different states. ${ }^{153}$

I submit that the approach of "judicial method and the policy-centered conflict of laws," with interest analysis at its base, is a sound way to deal with contract cases involving strong policies of the concerned states. It is true, of course, that because of the possibility of reliance on the law of a particular state and because of the common policy of all states to protect the legitimate expectations of the parties and to insure the stability of interstate commercial transactions, the displacement of the forum's law would be more frequent in contract cases than, for example, in the tort area. The forum may be more apt to conclude that the application of its law would be unfair or that the

147. 239 Ore. at 10,395 P.2d at 547. Under the traditional approach, the "public policy" exception was limited to the refusal to entertain a claim created in another state. RESTATEMENT OF CONFLICT OF LAWS $\S 612$ (1934). It did not justify the application of the forum's law to the transaction.

148. 239 Ore at 10, 395 P.2d at 547.

149. See Sedler, Characterization, suipra note 42 , at 78-81.

150. 239 Ore. at 15, 395 P.2d at 549. The court also observed that each state had a substantial interest that would be served or thwarted depending upon which law was applied and that in such case, "the public policy of Oregon should prevail and the law of Oregon should be applied." Id. at 16, 395 P.2d at 549.

151. The conflict was between what I call the "family law" policy of Oregon and the "contract" policy of California.

152. See B. CuRRIE, stipra note 35 , at 181-82. text.

153. For the problem posed by this approach, see notes 11-12 supra and accompanying 
conflict can be avoided by a more moderate and restrained interpretation of its own policy and interest. ${ }^{154}$ Nevertheless, where a true conflict is presented, the forum should apply its own law, and in such a case the application of its law is not likely to be unfair to the other party. The interest and fairness test that I am proposing is, of course, completely distinct in orientation from the new Restatement's state-of-the-most-significant-relationship test, although frequently it accords with the results reached by the courts that have been purporting to apply the Restatement rule..$^{155}$

Perhaps the best way to elucidate the implications of this suggested methodology is by contrasting it with the approach taken by the Restatement. This will be done through the analysis of a number of cases that illustrate the key issues involved. When only one state has an interest in the application of its law, and to apply the law of another state would frustrate that interest, a false conflict is presented; in such a case, the forum should apply the law of the only interested state. Among the contract precedents, this point is best illustrated by Intercontinental Planning Limited v. Daystrom, Inc., ${ }^{160}$ involving a claim for a finder's fee made by a New York broker against a New Jersey corporation. The plaintiff was engaged in bringing together American and European firms for the purpose of affiliation and merger. The defendant's president admittedly agreed to pay a finder's fee if a relationship were established with a certain foreign firm, but the proposed merger did not take place with the foreign firm, which was itself acquired by a larger company. The latter, however, proceeded to merge with the defendant, and the plaintiff contended that the defendant's president had orally agreed to extend the brokerage agreement to encompass that inerger. Under New York law, brokerage agreements came within the Statute of Frauds, and the original written agreement would not have been sufficient to cover the new merger. New Jersey had no applicable Statute of Frauds. The New York court applied New York's Statute of Frauds to bar the suit.

The court stated that its approach to conflicts questions arising in contract actions was to " apply the policy of the jurisdiction "most intimately connected with the outcome of [the] particular litigation"."167 It then considered the policies and interests of both states. One of the policies behind the New York

154. Again, I am not assuming that the forum is a disinterested third state, because this is generally an uncoinmon situation.

155. This lends credence to Professor Ehrenzweig's observation, see note 43 supra, that the state-of-the-most-significant-relationship test can be employed to achieve any result that the court desires. See also Phillips y. Englehart, 437 S.W.2d 158 (Mo. App. 1968) (The Missouri court found that the parties, an Iowa seller and a Missouri buyer, "intended" to submit themselves to Missouri law, which protected the buyer by preventing a complete forfeiture of the amount paid in upon repossession. Iowa law was to the contrary.)

156. 24 N.Y.2d 372, 248 N.E.2d 576, 300 N.Y.S.2d 817 (1969).

157. Id. at 382, 248 N.E.2d at 582, 300 N.Y.S.2d at 825 (citing Auten v. Auten, 308 N.Y. 155, 161). 
Statute of Frauds, it said, was to protect principals in the sale of a business interest from a finder's fee claim that is not supported by written evidence. Since New York was an international center for the purchase and sale of businesses, the state policy extended to foreign principals who utilized New York brokers. Moreover, affording foreign principals the greatest degree of protection against unsubstantiated claims of brokers would encourage the use of local brokers, thus contributing to the economic development of the state. Many of the negotiations in the instant case had occurred in New York; there had been an advertisement in a New York newspaper; and the principals had been introduced there. New Jersey, in contrast, had no interest in denying protection to a New Jersey corporation against a New York broker. Therefore a false conflict was presented, since the displacement of New York law would defeat a legitimate interest of New York without serving any comparable interest of New Jersey. 158

Daystrom may be compared with Denny v. American Tobacco Company. ${ }^{159}$ The plaintiff, a resident of California, solicited a finder's fee by sending a letter to an officer of a corporation having its principal place of business in New York, advising him that a California-based company might be for sale and that he should call if interested. No answer was sent in response to this letter, but the defendant eventually did acquire the California company. The plaintiff sued in California, contending that his services were the procuring cause of the acquisition and that he was entitled to recovery quantum meruit. The defendant pleaded the New York Statute of Frauds, which would bar any recovery, as in Daystrom. The California Statute of Frauds apparently presented no obstacle to quantum meruit recovery.

The court first attempted to apply the state-of-the-most-significant-relationship test. However, after noting the factual contacts with both states, it concluded that "[a] practitioner of the second Restatement would be hard put to say which of these states had 'the most significant relationship' with the 'contract' involved herein." ${ }^{160}$ It then moved into interest analysis. Conceding that both states might have an interest in applying their laws, it emphasized that the plaintiff had told the defendant to answer only if he were interested, that the answer would have to have come from New York, and that under New York law there could be no liability for a finder's fee absent a written agreement. It was of the opinion that while New York's interest in protecting its residents from the sort of claim involved here was clear, California's interest in allowing its residents to recover was much less apparent. In effect, it advanced a more moderate and restrained interpretation of California's policy

158. See also Cavers, Conflict of Laws: Roundtable Symposinm, 49 TEx. L. REV. 211, 222-23 (1971) ; Sedler, supra note 43, at 228.

159. 308 F. Supp. 219 (N.D. Cal. 1970).

160. Id. at 222 . 
and interest in order to avoid the conflict, and it consequently applied New York law. ${ }^{161}$

Under the analysis that I propose the imposition of liability under California law would, in this situation, have been clearly unfair. The defendant made no reply to the offer, and under New York law he could not incur liability merely by taking advantage of the "tip." He did nothing to bring himself within California law, so to speak, ${ }^{162}$ and for this reason the application of California law was, in a sense, not forseeable. ${ }^{103}$ As the court indicated, ${ }^{104}$ it would be possible to say that New York was the state of the most significant relationship to this issue. But the only reasonable justification for this conclusion would be that New York had a strong interest in applying its law, California's interest was much less clear, and the application of California law would have been unfair to the New York defendant. Localization in this situation can come only as the product of interest analysis. Any initial effort on the facts of Denny to localize the contract in either New York or California merely obscures the important questions of policy and fairness upon which the outcome should turn.

Lilienthal v. Kaufman, as previously noted, ${ }^{105}$ illustrates the clearest case of a true conflict-between Oregon's "family law" policy of protecting spendthrifts and California's contractual policy of protecting the legitimate expectations of the parties to a commercial transaction. The Oregon court chose not to subordinate its protective policy notwithstanding that the contract was localized in California. ${ }^{106}$ The result was indeed to defeat the expectations of the California creditor, but it is doubtful if he was any more surprised than the Oregon creditor who had also been met with this very unusual defense in a prior action against the same debtor. ${ }^{167}$ On the other hand, I see a difference between defeating contractual expectations in order to implement very important "anti-contractual" policies, as in Lilienthal, and defeating those expectations because of conflicting contractual policies. The very assumption of the Oregon law involved in Lilienthal was that contractual expectations had to be defeated in order to protect the spendthrift and his family. In contrast, Denny involved conflicting contractual policies of New York and California;

161. The "inore moderate and restrained interpretation of the forum's policy and interest" was considered to have been the basis for the decision in Bernkrant $v$. Fowler, 55 Cal. 2d 588, 360 P.2d 906, 12 Cal. Rptr. 266 (1961). See B. CuRRIE, sispra note 35, at 688-89 n.236. As the subsequent discussion will indicate, I have a soinewhat different explanation for the result in Bernkrant. See text accompanying notes 168-70 infra.

162. I am not, however, suggesting any notion of "submission to legislative jurisdiction." Cf. Scheer v. Rocknee Motors, 68 F.2d 942 (2d Cir. 1934).

163. Cf. People v. One 1953 Ford Victoria, 48 Cal. 2d 595, 311 P.2d 480 (1957).

164. 308 F. Supp. 219, 223 (N.D. Cal. 1970).

165. See notes 147-52 supra and accompanying text.

166. The Restatement suggests that when a party's domicile chooses to protect him, the domicile might, in consequence, be considered the state of the most significant relationship. But it does so quite grudgingly. See Restatement (Second) § 198, comment $b$, illus. 1 , at $632-33$.

167. See note 145 supra and accompanying text. 
and in the context of that case, it would have been unfair to apply California's contractual policy to the New York defendant.

To illustrate this point further, suppose that an Oregon businessman enters into an oral contract with a California businessman in California, the contract to be performed in that state. When the Oregon party breaches, suit is brought against him in Oregon. The contract is unenforceable under the Oregon Statute of Frauds; it is valid under Cahifornia law. In these circumstances, the Oregon court should refuse to allow the defense. ${ }^{168}$ The policies behind the Statute of Frauds are obviously contractual in nature, and all aspects of the contract were connected with California. Although in terms of pure interest analysis the case may appear to present a conflict of interests (Oregon is interested in protecting its resident defendant, whereas California is interested in protecting its resident plaintiff and in upholding contracts made in that state and to be perforned there), there are no countervailing anticontractual policies that would justify the application of Oregon law, as there were in Lilienthal. To put it another way, the court that decided Lilienthal would not have found it to be against its "public policy" to enforce a California contract that did not satisfy the Oregon Statute of Frauds. ${ }^{169}$ To refuse enforcement of a contract satisfying the Statute of Frauds of the state where it was to be performed in its entirety simply on the ground that the defendant was a resident of the forum state would be fundamentally unfair to the plaintiff and might well raise constitutional issues. ${ }^{170}$

Different considerations are present, however, when a strong anti-contractual policy such as spendthrift immunity is involved, and the state of the defendant's residence has a legitimate interest in applying that policy to protect the defendant and his family. Because of that interest, it may require the other contracting party, resident or non-resident, to suffer defeat of his expectations. The localizing test of "the state of the most significant relationship" does not focus on these important policy differences and presumably would require the same result in both cases because the contract was "centered" in California. ${ }^{171}$ Only a careful analysis in terms of interest and fairness will permit the court to make this very necessary distinction. ${ }^{172}$

The difference between a policy-centered approach and the Restatement's localizing test is further demonstrated by a consideration of cases involving oral contracts to will. The lcading case in this area is Bernkrant v. Fowler. ${ }^{173}$

168. See Sedler, Characterization, supra note 42 , at 83-84.

169. Sce Lams v. F.H. Smith Co., 36 Del. 477, 178 A. 651 (Super. Ct. 1935); Jackson v. Jackson, 122 Utah 507, 252 P.2d 214 (1953). 232-33.

170. Cf. Home Ins. Co. v. Dick, 281 U.S. 397 (1930) ; B. CuRRIE, supra note 35, at noted.

171. Both the negotiations and performance took place there, as the Oregon court

172. See A. EHRENZWEIG, supra note 4, at 475-79 (distinguishing between different kinds of incapacity).

173. 55 Cal. 2d 588, 360 P.2d 906, 12 Cal. Rptr. 266 (1961). 
The plaintiffs were Nevada residents who had acquired an apartment building in that state, giving a purchase money mortgage for about $\$ 33,000$. The seller, a California resident at the time of his death (and for purposes of the point in issue assumed to have been one at the time of the agreement), wanted the buyers to refinance the transaction. He orally stated that he would "make a sporting proposition" and provide in his will that any debt remaining at the time of his death would be forgiven and cancelled in exchange for a partial payment and refinancing of the obligation. ${ }^{174}$ The requested financing was carried out, which reduced the debt by some $\$ 13,000$, at an out-of-pocket cost to the plaintiffs of approximately $\$ 800$. A year-and-a-half later the seller died, and his will neither forgave the debt nor directed cancellation of the notes. The plaintiffs then brought suit in California, seeking cancellation of the obligation.

Under Nevada law the oral contract was found to be enforceable, but it was assumed to be invalid under the California Statute of Frauds applicable to provision by will. The court refused to apply the Statute of Frauds despite an apparent interest in protecting California estates from false claims. It emphasized that the contract had been made in Nevada, performed by the parties in that state, and involved the refinancing of obligations arising from the sale of Nevada land and a debt secured by this land. The court referred to the common policy of both states to protect the reasonable expectations of the parties and concluded that, because California would have no interest in applying its Statute of Frauds until the death of the promisor, the plaintiffs

were not bound to know that California's statute might ultimately be invoked against them. Unless they could rely on [Nevada] law, they would have to look to the laws of all the jurisdictions to which [the promisor] might move regardless of where he was domiciled when the contract was made..$^{175}$

Professor Currie hailed the decision in Bernkrant as an example of moderate and restrained interpretation of the forum's policy and interest, demonstrating that "the method of governmental interest analysis need not necessarily produce egocentric or provincial results."178 In this instance, application of the Restatement's technique would have produced an identical result. Certainly Nevada would be regarded as the state having "the most significant relationship" under the principles of section 188, since all the factual contacts relating to the transaction were massed there.

But consider the following hypothetical situation: ${ }^{177}$ The decedent, a rich California widow, had a summer home in Nevada where she spent ap-

174. 8 Cal. Rptr. 326, 328 (Dist. Ct. App. 1960).

175. 55 Cal, $2 \mathrm{~d}$ at 596, 360 P.2d at $910,12 \mathrm{Cal}$. Rptr. at 270 (1961).

176. B. CuRRIE, supra note 35 , at 688-89 n.236.

177. This case is similar to Emery v. Burbank, 163 Mass. 326, 39 N.E. 1026 (1895), with the elimination of all other factual contacts with the decedent's domicile. 
proximately four months each year. In Nevada she orally agreed with the plaintiff, a local resident who had never set foot in California and had no intention of going there, that if the plaintiff would keep house for her during these summer visits, she would leave the plaintiff half of her estate by will. The arrangement continued until the decedent's death five years later. The decedent did not include the promised bequest in her will, and the plaintiff brings suit against the executor in California to enforce the oral contract to will. The executor, as in Bernkrant, asserts the California Statute of Frauds applicable to provision by will.

Is this case sufficiently like Bernkrant so that California should apply Nevada law and allow the claim? Under the state-of-most-significant-relationship approach it is virtually identical, since the factual contacts are once again massed entirely in Nevada. In terms of policy and interest, though, it is a very different matter because it involves a true contract to will, which Bernkrant, on closer analysis, did not. ${ }^{178}$ The purpose of a rule prohibiting oral contracts to will would seem to be to prevent the decedent from passing a portion of his estate (and thus disappointing his heirs) unless he executes a document satisfying the requirements of a formal will. But the decedent in Bernkrant was not in fact trying to pass anything to the plaintiffs by will. He was engaged, in his words, "in a sporting proposition," and he hoped that he would live long enough for the entire debt to be repaid during his lifetime. Thus the Bernkrant transaction should be regarded as an ordinary business arrangement for the refinancing of a mortgage, with the addition of a contingent provision forgiving the debt by will if the decedent "loses his gamble." Certainly it should not be viewed as a transaction of the kind with which the legislature was concerned when it enacted the Statute of Frauds applicable to provision by will. ${ }^{179}$ If the problem is examined from this perspective, ${ }^{180}$ it is apparent that California has no legitimate interest in applying its Statute of Frauds to a contractual arrangement that was connected solely with Nevada. ${ }^{181}$

In the hypothetical case, however, the decedent was obviously attempting to pass a portion of her estate by the oral agreement-the very act that the legislature was seeking to prevent by means of the Statute of Frauds. Because the court is dealing with an actual contract to will, it must be concerned with implementing the decedents' estates policy reflected in the statute, a policy

178. See Sedler, Characteriation, supra note 42, at 92-94.

179. Perhaps this "promise to will" was within the letter of California's Statute of Frauds; but this may be questioned. See id. at 93 . In a purely domestic case it is conceivable that a court, if forced to confront the specific question, would decide that the transaction did not involve a contract to will within the meaning of the statute because the decedent did not really intend to make a testamentary disposition.

180. As to identification of the problem area generally, see Sedler, Characterization, supra note 42 , at $42-48$.

181. This case raises the same policy issues as the hypothetical example involving the Oregon Statute of Frauds. See notes 168-70 sipra and accompanying text. 
that deliberately frustrates the expectations of the contracting parties in order to protect the decedent's heirs. Nevada, on the other hand, may have an interest in applying its law so as to enable the Nevada resident to recover on the oral agreement, which would have been valid in his home state. ${ }^{182}$ In this situation a true conflict is presented, and California, as the forum state, might be expected to apply its own law..$^{183}$

The difference between Bernkrant and the hypothetical case lies in the distinction between an essentially commercial agreement and a true contract to will. ${ }^{184}$ Nevertheless, in both cases the factual contacts are the same, and each contract is centered in Nevada. If the drafters of the Restatement wish to imply that in the case of true contracts to will the state of most significant relationship under section 188 will necessarily be the decedent's domicile, they should say so; but they do not. ${ }^{185}$ Moreover, there is nothing in the Restatement's methodology that tells a court how to distinguish between these two situations, which are quite different although the factual contacts with the respective states are the same. In contrast, a policy-centered approach makes this distinction abundantly clear and enables the court to focus on the differing policies and interests of the respective states in the two situations.

This kind of policy analysis was employed by a California intermediate appellate court in Younker v. Manor. ${ }^{186} \mathrm{~A}$ deficiency action was brought against a California corporation that had guaranteed a note for the purchase of Nevada land. California had a statute barring deficiency judgments; Nevada did not. The plaintiffs argued that all of the significant contacts were in Nevada: the note had been executed there, it was payable there, and the land was situated there. In refusing to entertain the action, the court distinguished between the "real property" aspects of the transaction, which had already been subject to Nevada law by the foreclosure proceeding, and the deficiency or "personal" aspects. With respect to the latter, California's policy was to protect buyers of land from personal judgments. Thus the state had an interest in applying that policy to "protect the solvency" of the California defendant. Assuming Nevada had an interest in allowing its residents to obtain the maximum recovery, its policy conflicted with that of California. The court, in applying California law, emphasized that there was no unfairness to the creditor, especially in light of evidence that the plaintiff had believed at the time of the transaction that Nevada law also prohibited deficiency judgments. ${ }^{187}$ More

182. See Sedler, Characterization, subra note 42, at 94-95. I question whether Nevada should apply its law here.

183. See notes 13 \& 101 supra and accompanying text.

184. As to the "commercial" nature of the contract in such a situation, sec $R$. WEINTRAUB, supra note 1 , at 288-91.

185. It does not discuss contracts to will separately, but refers to Bernkrant and Emery as "cases of particular interest involving the statute of frauds in a choice of law setting." RESTATEMENT (SECOND) \& 199.

186. 255 Cal. App. 2d 431, 63 Cal. Rptr. 197 (1967).

187. It was claimed that the president of the defendant corporation had been told 
importantly, at all times the plaintiff had known that the defendant was a California corporation ${ }^{188}$ and that its principal assets were located there. It does not seem unfair to require the plaintiff in these circumstances to be aware of the California anti-deficiency statute, and thus California could legitimately apply its own law.

In a similar vein is the decision in Potlatch No. 1 Federal Credit Union $v$. Kennedy. ${ }^{189}$ A Washington marital community was sued in their home state by an Idaho creditor on a note that the husband had executed as surety for his brother. The note and the co-maker's statement had been prepared by the plaintiff at its Idaho office, and the funds had been transferred to the debtor there. Under Washington law, community property was not liable for the suretyship debt of one of the parties unless the community had benefited by the obligation, which was not the case in this instance. Idaho law was to the contrary. The Washington court had previously adopted the state-of-the-mostsignificant-relationship rule ${ }^{190}$ and purported to apply it in the Potlatch case. It emphasized, however, that the contacts with the respective states were merely "guidelines indicating where the interests of particular states may touch the transaction in question." 191 The court then proceeded to approach the case in terms of interest and fairness and concluded that Washington had a clear interest in applying its law, a true policy conflict having arisen. Since the Idaho creditor had known that he was dealing with Washington residents and that most, if not all, the community property was located there, the application of Washington law would not give rise to any unfairness. ${ }^{192}$ On the issue of the commumity's liability, therefore, Washington was conceded to be the state of the most significant relationship. This case illustrates how the new Restatement test of most significant relationship can be used to justify an analysis that has been carried out in terms of interest and fairness. ${ }^{193}$ In light of this essentially post hoc application, one may well ask whether the Restatement's methodology has any independent utility. Indeed, it would be far more advantageous for the courts to proceed on the basis of interest

by the plaintiff that "there was nothing to worry about because the law was just like in California in regard to personal liability on purchase money deeds of trust." "This was denied by the plaintiff. 255 Cal. App. $2 \mathrm{~d}$ at 433, 63 Cal. Rptr. at 199.

188. It was on this basis that the court distinguished Bernkrant. Id. at $438,63 \mathrm{Cal}$. Rptr. at 202.

189. 76 Wash. 2d 806, 459 P.2d 32 (1969).

190. Baffin Iand Corp. v. Monticello Motor Inn, Inc., 70 Wash. 2d 893, 425 P.2d 623 (1967) ; Pacific States Cut Stone Co. v. Goble, 70 Wash. 2d 907, 425 P.2d 631 (1967). In both of these cases the issue was whether community property was subject to an obligation incurred by Washington residents. Since Washington law made it subject to that obligation, no conflict of any sort was presented. It was therefore unnecessary for the court to delve into an analysis of the state-of-the-most-significant-relationship rule. See R. WeINTRAUB, supra note 1, at 278-80.

191. 76 Wash. $2 \mathrm{~d}$ at 810,459 P.2d at 35 .

192. See Sedler, Characterization, supra note 42, at 89 n.333.

193. See R. WeINTRAUB, supra note 1 , at 276-77. 
analysis from the outset, without struggling to bring their reasoning artificially within the framework of the Restatement (Second).

One area in which the outcome under the Restatement's methodology clearly coincides with the result under an interest-and-fairness approach is that of life insurance. Here strong regulatory policies are present, ${ }^{104}$ and the insured's domicile will apply its law to protect him from what it regards as overreaching on the part of the insurer. ${ }^{105}$ By the same token, where the insured is not entitled to protection under the law of his domicile, it is reasonable to deny him such protection. ${ }^{108}$ The law of the insured's domicile can be ascertained and relied on by the parties, and the domicile is undoubtedly the most concerned state. ${ }^{107}$ Recognizing this, the Restatement says that the domicile of the insured is presumptively the state of the inost significant relationship as to life insurance contracts. ${ }^{198}$ The same approach can be taken with respect to accident insurance. ${ }^{199}$ In the case of group life insurance, however, it is proper to look to the law of a single state to determine the rights of all the members of the group. As a practical inatter, there will usually be an express choice of law in the inaster contract, and this choice will be recognized by the state of the insured's domicile. ${ }^{200}$

In areas other than life insurance contracts, the Restatement's approach - maintaining that the state of the most significant relationship governs contractual obligations and presumptively defining that state by a catalogue of rules-is less helpful. Under section 193, for example, the "principal location of the insured risk" is presumed to be the state of the most significant relationship in casualty insurance contracts. As to automobiles the principal location of risk is said ordinarily to be the place where the automobile is garaged. ${ }^{201}$ But consider a situation such as that found in Haines v. Mid-

194. Thus, as pointed out earlier, an express choice of law will not be recognized. See notes $107-10$ supra and accompanying text.

195. See, e.g., Zogg v. Penn Mut. Life Ins. Co., 276 F.2d 861 (2d Cir. 1960). 1963).

196. See, e.g., Fleet Messenger Serv. v. Life Ins. Co., 315 F.2d 593, 597 (2d Cir.

197. See Restateminet (Second), Explanatory Notes § 192, comment c, at 601-02;

A. EHRENZWEIG, supra note 4 , at 515-16.

198. Restatement (Second) \& 192.

199. See, e.g., Kievit v. Loyal Protective Life Ins. Co., 34 N.J. 475, 170 A.2d 22 (1961) Johnston v. Commercial Travelers Mut. Accident Ass'n, 242 S.C. 387, 131 S.E.2d 91 (1963). The Restatement states that the principal location of the insured risk with respect to accident policies will usually be in the state of the insured's domicile. RESTATEMENT (SECOND), Explanatory Notes \& 193, comment $b$, at 611 .

200. See Detroit Greyhound Employees Federal Credit Union v. Aetna Life Ins. Co, 7 Mich. App. 430, 151 N.W.2d 852 (1967); Kahn v. Great-West Life Assurance Co., 61 Misc. 2d 918, 307 N.Y.S.2d 238 (Sup. Ct. 1970) ; cf. Boseman v. Connecticut General Life Ins. Co., 301 U.S. 196 (1937); REstatenENT (SECOND), Explanatory Notes \& 192, comment $h$, at 605-06. As Professor Ehrenzweig has stated:

Group insurance contracts are usually freely negotiated between the insurer and representatives of the group. Provisions contained in such contracts, including stipulation of an applicable law are therefore subject to the Rule of Validation. For "the master policy rather than the certificate sent to the insured member is generally held to be the contract of insurance."

A. EHRENZWEIG, supra note 4 , at 512 (footnote omitted).

201. Restatement (Second), Explanatory Notes \& 193, comment b, at 611 . 
Century Insurance Co. ${ }^{202}$ The events in that case occurred in a "functional socio-economic and mobility area"203 consisting of LaCrosse, Wisconsin and LaCrescent, Minnesota. ${ }^{204}$ At the time of the accident, the parties-husband and wife-lived on the Minnesota side of the state line, and their automobile was garaged there. The husband worked on the Wisconsin side, however, and the insurance contract had been negotiated and executed in the insurer's office there. The contract contained a family exclusion clause, which at the time of contracting was valid under Minnesota law but invalid under Wisconsin law. The accident occurred in Wisconsin. The wife brought suit against her husband in Wisconsin and joined the insurer under Wisconsin's direct action statute. The insurer moved to dismiss in reliance on the family exclusion clause. Wisconsin had previously characterized validity of a family exclusion clause as a "contract problem," 205 and the question was whether Wisconsin or Minnesota law applied to this issue. By the time of the suit the wife had apparently separated from her husband and taken up residence on the Wisconsin side of the line. Also, Minnesota had changed its law in the interim by adopting a statute invalidating such exclusionary provisions. The court purported to apply the state-of-the-most-significant-relationship test but interpreted it to authorize interest analysis in a case of this nature. In its discussion, the court rejected the idea that the automobile in this case could be said to have a single principal location in either state ${ }^{206}$ and went on to observe that "[a]t best the significant contacts are split between the two states."207 At this point, it took a pure policy-centered approach, treated the case as a true conflict, and applied Wisconsin law as the "better law."208

Although Minnesota's invalidation of family exclusion provisions minimized its interest and the plaintiff's change of residence strengthened Wisconsin's interest, it is doubtful that either of these changes affected the choice-of-law decision. In view of Wisconsin's policy of allowing recovery to

202. 47 Wis. 2d 442, 177 N.W.2d 328 (1970).

203. See Sedler, The Territorial Imperative: Automobile Accidents and the Significance of a State Line, 9 DuQ. L. REv. 394, 398-99, 407-08 (1971):

204. See 47 Wis. $2 d$ at 449,177 N.W.2d at 332.

205. See Urhammer v. Olson, 39 Wis. $2 d$ 447, 159 N.W.2d 688 (1968).

206. The Restatement appears to take a contrary position, suggesting that the place where an insured automobile is garaged is ordinarily to be regarded as the location of the risk. RESTATEMENT (SECOND), Explanatory Notes $\S 193$, comment $b$, at 611 . But see $i d$. comment $a$, at 610 . (With regard to vehicles used as interstate carriers, "[t]here may be no principal location of the insured risk.")

207. 47 Wis. $2 \mathrm{~d}$ at 450,177 N.W.2d at 332 . The place of negotiation and place of contracting were in Wisconsin. The place of performance was "equally divided," and the location of the subject matter was in both states. Minnesota was the domicile of the parties.

208. 47 Wis. $2 \mathrm{~d}$ at 451,177 N.W.2d at 333. The "better law" has been applied by Wisconsin courts when it is Wisconsin law that is "better." See Conklin v. Horner, 38 Wis. 2d 468, 157 N.W.2d 579 (1968); Heath v. Zellmer, 35 Wis. 2d 578, 151 N.W.2d 664 (1967). However, in Satchwill v. Vollrath Co., 293 F. Supp. 533 (E.D. Wis. 1968), involving a true conflict as to limitation of damages for wrongful death, the court applied Wisconsin law even though it was not the "better" one. When a court applies the "better law," that law, not coincidentally, is usually its own. 
all persons injured within its borders, ${ }^{208}$ it had an interest in applying local law. Minnesota's interest was to protect its insurer. In the case of a true conflict, the forum can be expected to apply its own law. Here the application of Wisconsin law was certainly not unfair to the insurer, which had its office on the Wisconsin side, and which, in any event, could be expected to foresee the application of either state's law in that functional socio-economic and mobility area. The state-of-the-most-significant-relationship test again was of no assistance to the court in arriving at its decision. If anything, it was a hindrance, an unhelpful ritual that had to be performed before the court could proceed to analyze the problem meaningfully in terms of interest and faimess.

When the insured has changed his domicile after the execution of the contract, Clay v. Sun Insurance Office, $L t d .{ }^{210}$ makes it clear that his new domicile may constitutionally apply its own law to protect him against the insurer. The new domicile is justified in doing so because of its interest in safeguarding the welfare of its residents (or, in the case of life insurance, in carrying out their beneficial intentions). There is no unfairness to the insurer, who could foresee the change of domicile.211

My fundamental thesis is that the interest and fairness test, which serves to define the constitutional dimensions of choice of law in contract cases, as in all others, ${ }^{212}$ should also be employed to make the basic choice-of-law decision as to all matters involving a strong policy of the concerned states. ${ }^{213}$ In actual practice, those courts that have abandoned the "place of contracting" rule of the original Restatement are generally employing the interest-and-fair-

209. See Conklin v. Horner, 38 Wis. $2 d$ 468, 157 N.W.2d 579 (1968).

210. 377 U.S. 179 (1964).

211. See RESTATEMENT (SeCOND), Explanatory Notes \$ 193, comment d, at 613. In Quarty v. Ins. Co. of North America, 244 So. 2d 181 (Fla. App. 1971), the court held that the Florida statute involved in Clay, which invalidated built-in limitation periods, did not apply. The insured was not a resident of Florida at the time of the loss, but had moved to Florida by the time of the suit. As to the applicability of the law of the insured's new residence to automobile insurance contracts, compare American Service Mut. Ins. Co. v. Bottum, 371 F.2d 6 (8th Cir. 1967), with Employers' Liab. Assurance Corp. v. Aresty, 11 App. Div. 2d 331, 205 N.Y.S.2d 711 (1st Dep't 1960), aff'd, 11 N.Y.2d 696, 180 N.E.2d 916, 225 N.Y.S.2d 764 (1962), and Security Ins. Group v. Emery, 272 A.2d 736 (Me. 1971).

212. See generally Sedler, supra note 203 , at 402-04. The last case in which the Supreme Court, by a 5-4 decision, held unconstitutional a state court's choice of law, Order of United Commercial Travelers v. Wolfe, 331 U.S. 586 (1947), involved insurance contracts between a fraternal benefit association and its members. The Court held that, as a matter of full faith and credit, the law of the state where the association was organized had to govern in order to guarantee equality of treatment among the members. Id. at 610 . There is a distinction, I think, between the rights of a member under the insurance contract and the liability of members for statutory assessments. In Supreme Council of Royal Arcanum v. Green, 237 U.S. 531 (1915), the Court first enunciated the principle that a uniform law had to apply to assessments of this nature. In terms of interest and fairness, there is no reason why the policyholder's home state should not be able to apply its law invalidating built-in limitations provisions, and it is doubtful whether Wolfe would be decided the same way today.

213. Another example of the situation where the forum will apply its own law in order to implement a strong policy is the matter of covenants not to compete. Sce, c.g., Credit Bureau Management Co. v. Huie, 254 F. Sunp. 547 (E.D. Ark. 1966); Davis v. Ebsco Indust., Inc., 150 So. $2 d 460$ (Fla. App. 1963). 
ness test to resolve questions that touch upon significant governmental interests. They may pay lip service to the state-of-the-most-significant-relationship test; but as Haines and the other cases indicate, this formulation often proves an obstacle to arriving at a proper result. When presented with a true conflict, the courts have almost invariably ended by applying their own law, as illustrated by Lilienthal, Younker, Potlatch, and Haines. This is so despite academic criticism $^{214}$ and the suggestion of numerous alternatives for resolving true conflicts. ${ }^{215}$ On the other hand, because of the common policy of protecting the legitimate expectations of the parties and insuring stability in interstate commercial transactions and a concern with fairness to non-resident contracting parties, the courts are more disposed to try to avoid the confiict by a moderate and restrained interpretation of their own policy and interest, as in Bernkrant and Denny. The state-of-the-most-significant-relationship test, with its amalgam of contacts and policy, merely obscures the real issues. Where strong policies are involved, an approach in terms of interest and fairness is a much more realistic way to analyze the problems and is far more likely to produce sound results.

\section{Chotce of Law in Clatus of Usury}

The approach of judicial method and the policy-centered conflict of laws seems to me particularly appropriate for dealing with claims of usury. Usury laws favorable to debtors reflect a strong policy of protecting necessitous borrowers against overreaching on the part of lenders, who are usually economically stronger. ${ }^{216}$ This is certainly true of most consumer loans. We should, however, draw a distinction with regard to commercial loan transactions, in which bargaining power between the parties is generally equal. ${ }^{217}$ This distinction between consumer and commercial loans is recognized in the laws of many states, which either preclude corporations from asserting the defense of usury or allow higher interest rates for corporate borrowers. ${ }^{218}$ On the other hand, where corporations are permitted to defend on grounds of usury, the state policy protecting commercial borrowers may be fully as strong as that designed to shelter individuals.

The states have employed widely divergent sanctions to deal with usury,

214. As illustrating the almost universal academic criticism of Lilienthal, see, e.g., D. Cavers, The Choice of Iaw Process 189-93 (1965).

215. See, e.g., id. ch. 7; R. WeInTRAuB, supra note 1, at 284-92. Professor Ehrenzweig's rule of validation approach would, of course, be another way to resolve true conflicts. Interestingly, he notes that in international cases the forum is more likely to invalidate contracts in order to implement its own policy. See A. EHRENZWEIG, supra note 4 , at 486 .

216. See generally Comment, Usury in the Conflict of Laws: The Doctrine of Lex Debitoris, 55 CALIF. L. REv. 123, 126-37 (1967).

217. See id. at 200-02, 206-09; A. EHRENZWEIG, supra note 4, at 482-84.

218. See Comment, supra note 216 , at $207-08$, and the review of state laws in $i d$. at 207 n.441. 
and the nature of the sanction as well as the permissible rate of interest may demonstrate the "strength" of a state's policy against usury. Some states merely deprive the lender of the excess interest and fully enforce the contract as to the remainder of the loan..$^{210}$ Others require a forfeiture of all interest. ${ }^{220}$ Still others require the lender to disgorge a multiple of the interest charged or taken. ${ }^{221}$ At the other end of the spectrum, some states (including New York) hold that the contract is completely unenforceable, resulting in a forfeiture of the entire interest and principal. ${ }^{222}$ Approximately one-third of the states also impose criminal penalties.223 When a state has a strong policy against usury, it has an interest in applying its own law to implement that policy whenever it has a legitimate occasion for doing so. Appropriate situations will arise, for example, when the borrower is a resident of the state or when the lender has its principal place of business there..$^{224}$

The Second Restatement's approach to usury not only ignores the policy and interest of concerned states, but goes so far as to abandon the state-ofmost-significant-relationship formulation, under which at least some consideration can be given to the policies reflected in differing laws. In its place, section 203 of the Restatement substitutes a "rule of validity" that provides:

The validity of a contract will be sustained against the charge of usury if it provides for a rate of interest that is permissible in a state to which the contract has a substantial relationship and is not greatly in excess of the rate permitted by the general usury law of the state of the otherwise applicable law under the rule of $\S 188 .{ }^{225}$

A "substantial relationship" may be found in any state where the borrower is domiciled, where the loan is to be repaid, where the lender has his principal place of business, or where the loan was negotiated. The only qualification is that these contacts cannot be "manipulated."226

The contrast between the Restatement's approach and one based on interest and fairness may be illustrated by the following example. The maximum rate of interest under the law of the borrower's state is $6 \%$; under the law of the lender's state it is $8 \%$. The note was made and is payable in the lender's state. The negotiations preceding the loan occurred in the borrower's state. In terms of interest analysis, this case would appear to present a true conflict. The lender's home state is interested in allowing him to charge the

219. See id. at 232 n.567.

220. See id. at 232 n.569.

221. See id. at 233 nn. $570-71$.

222. See $i d$. at $233 \mathrm{nn} .572-74$.

223. See id. at 233 n.575.

224. When the lender has his principal place of business in a state, and some of the events took place there, that state has an interest in applying its law in favor of a non-resident borrower in order to implement the admonitory policy reflected in that law. See notes $257-58$ infra and accoinpanying text.

225. RESTATEMENT (SECOND) \& 203.

226. See id., Explanatory Notes \& 203, comment c, at 651-52. 
maximum rate permitted under its law, and the borrower's home state is interested in protecting him from what it considers to be the rapacity of economically superior lenders. The law of either state is "foreseeable" by the parties because the loan transaction has factual connections with both states. Certainly the borrower's home state is justified in applying its own law. But under the Restatement's approach, since the contract bears a "substantial relationship" to the lender's state, under whose law it is not usurious, the borrower's state would be expected to subordinate its own protective policy and to apply the law that would uphold the contract.227

While conceding that "usury laws are designed to protect a person against the oppressive use of superior bargaining power and thus represent an important policy of the enacting state,"228 the Restatement justifies its rule of validity on the ground that:

[O] rdinarily, the permissible rate of interest will vary only slightly from state to state. Upholding a contract against the charge of usury by the application of the local law of one state, which has a substantial relationship to the transaction and the parties, can hardly affect adversely the interests of another state when the stipulated interest is only a few percentage points higher than would be permitted by the local law of the other state.229

This is a rather strange assumption to make at a time when a fractional change in interest rates produces substantial fluctuations in the stock market and sends economists and investors looking for portents of economic growth or decline. It becomes ridiculous when applied to anything other than a very short-term transaction. One may ask whether the drafters of the Restatement, if offered a home mortgage loan at $8 \%$ instead of $6 \%$, would assume that the difference in interest rates would "hardly affect their interests." Even if this were only a ten-year loan of $\$ 10,000$, a $2 \%$ differential would mean an added payment of between $\$ 1100$ and $\$ 2000$ (depending upon whether interest was calculated on the declining balance method)-an additional $11 \%$ to $20 \%$ of principal. 230

Moreover, the difference in the permissible rate of interest is not merely a difference in detail. Depending upon the amount of permissible interest and the nature of the sanction employed, it represents a policy judgment whether to favor borrowers or lenders as a class. ${ }^{231}$ All states have a policy of allowing interest. They also have in common a policy of imposing some limitations on the lender's power to exact such interest. But where the line is drawn between

227. See id., Explanatory Notes § 203, comment $c$, illus. 4, at 652 .

228. Id. comment $e$, at 653-54. The Restatement also says that an express choice of law is not relevant, but only because of the "liberality of the present rule." Id. at 653 .

229. Id., comment $b$, at 650 . Professor Weintraub agrees with this analysis. See R. WEINTRAUB, supra note 1 , at $286-87$.

230. See also Comment, supra note 216 , at 229 .

231. The majority of states have maximum rates between $6 \%$ and $12 \%$. B. CurRaN, TRENDS IN CONSUMER CREDIT LEGISLATION 15 (1965). Far from supporting the conclusion that the difference in usury laws is "one of detail," such a differential demonstrates to me a policy judgment whether to favor lenders or borrowers. 
these competing policies and the nature of the sanction employed in response to a violation cannot be treated as inconsequential; these are important policy judgments having significant economic and social consequences. ${ }^{232} \mathrm{~A}$ state such as New York, which allows only $6 \%$ and provides that usurious contracts are completely unenforceable, has made a policy judgment favoring borrowers as a class over lenders. If a New York borrower enters into a contract with a. lender from a state that allows $10 \%$ interest and provides that only excess interest is forfeited, the conflict between New York's obvious policy of favoring borrowers and the other state's equally obvious policy of favoring lenders is not a mere "difference in detail." The conflict between the policy of borrower protection and the policy of lender protection has been recognized with respect to small loan laws, ${ }^{233}$ even by the Restatement, ${ }^{234}$ and the same conflict exists between general usury laws that differ in the rate of interest and in the sanctions employed. In no sense can the rule of validity be justified in usury cases on the ground that these differences "can hardly affect adversely the interests" of a concerned state.

The real reason for the rule of validity, as the practice of courts indicates, relates more to the difference in sanctions than to the "similarity" of interest rates. In the "leading case" purportedly establishing the rule of validity, Seeman v. Philadelphia Warehouse Co., ${ }^{235}$ the loan was usurious under the laws of both states (New York and Pennsylvania) to which the transaction bore a "substantial relationship." Under New York law, usurious contracts are, as previously indicated, completely unenforceable. Under Pennsylvania law only the mildest sanction, forfeiture of excess interest, is imposed. The "rule of validity" that the Court ostensibly followed in applying Pennsylvania law was, in effect, a rule that the lender was entitled to escape with the lightest sanction.

In the more recent case of Crisafulli $v$. Childs, ${ }^{236}$ again involving New York and Pennsylvania, the New York court was more candid in admitting what it was doing and why. The loan was a commercial rather than a consumer transaction and involved the financing of a $\$ 35,000$ cooling machine. If New York law applied, the borrower would receive a "windfall" in the amount of $\$ 15,000$. If Pennsylvania law applied, the borrower would have to pay that sum, subject only to a deduction of $\$ 165$ representing excess interest already paid. The court related the rule of validity to the difference in sanctions and observed that:

232. See Comment, supra note 216 , at $245-46$.

233. See R. WeINTRAUB, supra note 1, at 287. See also Personal Fin. Co. v. Gilinsky Fruit C.o., 127 Neb. 450, 255 N.W. 558 (1934), cert. denied, 293 U.S. 627 (1935) ; Standard Agencies, Inc. v. Russell, 100 Ohio App. 140, 135 N.E.2d 896 (1954); cf. Kinney Ioan \& Fin. Co. v. Sumner, 159 Neb. 57,65 N.W.2d 240 (1954).

234. See Restatement (SECoND), Explanatory Notes $\& 203$, comment $f$, at 654 . The Restatement leaves open whether the rule of validity would be applied by the courts to small loan laws.

235. 275 U.S. 403 (1927).

236. 33 App. Div. 2d 293, 307 N.Y.S.2d 701 (4th Dep't 1970). 
[T] he application of the rule would produce a just result herein. The voiding of the contract would result in a windfall to plaintiffs of the sum of $\$ 15,000$ in addition to the $\$ 5,000$ discount they received on the purchase price of the machinery by reason of the loan. It is recognized that "It is the necessitous individual who is protected by legislation against usury, because the power of the lender to relieve the borrower's needs creates the opportunity for oppression." But such is not this case. Plaintiffs apparently were represented throughout by an attorney. The original contract of purchase and sale with Eastern provided that the prospective loan should carry an annual interest rate of $10 \%$. It was not, however, until the loan, providing for such rate, and one payment thereon, had been made that plaintiffs suddenly discovered that the agreement possibly could be invalidated. ${ }^{237}$

As Crisafulli indicates, the real purpose of the rule of validity is probably to protect lenders as a class from what the courts regard as harsh forfeiture provisions found in the laws of some states. ${ }^{238}$ The case also demonstrates that the stakes can be very high when the sanctions differ, and it may be asked just how many cases do arise where the difference is merely one of rates rather than of sanctions. ${ }^{239}$

Professor Ehrenzweig, a strong proponent of the rule of validity generally, says that the usurious contract is "probably the most important case in which that rule does not apply."240 His approach to usury questions is to apply the law of the forum (which will usually be the borrower's home state) unless for some reason the lender was entitled to expect the application of the law of a state with a more liberal rule. ${ }^{211}$ It has also been argued that, "in the absence of an overriding policy to the contrary," the law of the borrower's domicile should be applied in all cases between parties from different states.242

There is certainly no justification for applying a rule of validity to protect lenders as a class from heavy sanctions imposed by the legislature of a concerned state. In Crisafulli the court viewed the borrower as seeking an "undeserved windfall." But it must not be forgotten that the lender was at the same time attempting to exact a rate of interest that it knew to be usurious under the laws of both New York and Pennsylvania. It seems to me that the borrower's conduct in trying to void the agreement and thereby obtain the "windfall" was no more "reprehensible" than the lender's efforts to secure an illegal rate of interest in the first place. The policy of New York, as reflected in its usury laws, was specifically to allow the borrower to obtain this "windfall" in order to deter such conduct on the part of the lender. In a purely domestic case, the New York court would be required to implement the

237. Id. at 297, 307 N.Y.S.2d at 705 (citations omitted).

238. See Comment, supra note 216 , at 235-36 n.586.

239. See id. at $236-37$.

240. A. EHRENZWEIG, supra note 4, at 482.

241. Id. at 484 . The borrower would also not be protected where he was a resident of a state with a more liberal law.

242. Comment, supra note 216 , at $183,250-52$. 
legislative policy. ${ }^{243}$ However, because a foreign element was present, the court was able to thwart this policy. It has been contended that the "courts in those states with heavy forfeiture provisions have generally strained to avoid imposing forfeitures upon foreign lenders."244 In analyzing this process, one commentator has noted:

The result is paradoxical: The stronger a state's legislative policy against usury, the more apt the courts are to disregard that policy. As the punitive sanctions become increasingly stringent, it is correspondingly easier for a foreign lender to evade them with impunity. With a kind of perverse logic, a court's unwillingness to overturn a transaction grows with the amount of the loan and the usurious interest taken. Although many courts might be persuaded to enforce the forfeiture of a few hundred dollars, few could be persuaded to declare a forfeiture of many thousands. Ironically, if the lender is careful to extract usurious interest upon comparatively large loans, his invulnerability is virtually guaranteed. Heavy as the increase in the borrower's burden of payment may be under the loan contract, it is far outweighed by the court's abhorrence of an even greater forfeiture accompanied by a correspondingly large windfall to the borrower. ${ }^{245}$

Stated simply, the courts are demonstrating their preference for lenders as a class by enabling them to avoid severe forfeiture provisions. To accomplish this they will go so far as to uphold a contract that is patently usurious under the law of the state with the more severe sanction. Even if this goal of preventing forfeitures is regarded as justifiable, it could certainly be achieved less disingenuously than by invoking the rule of validity. To do so, the court would declare the contract invalid, as is done when it is found to be usurious under the laws of both states. However, the less severe sanction would be applied, as in Crisafulli, on the ground that this "would produce a just result herein."246 In any event, the policy to protect lenders as a class in interstate loan contracts should be stated explicitly and candidly, rather than being obscured by the application of a so-called rule of validity.

If the rationale for the rule of validity is that the difference in permissible interest rates is merely a difference in detail, ${ }^{247}$ that justification is economically unsound and ignores the practical effect of the divergent policies that may be reflected in the differing interest rates and sanctions. If, on the other hand,

243. See id. at 234 \& nn. $580-81$.

244. Id. at 235 .

245. Id. (footnotes omitted).

246. 33 App. Div. at 297, 307 N.Y.S.2d at 705. In effect, the court would be applying the law of the forum insofar as it made the transaction usurious and the law of the other state as to the penalty. Cf. Kilberg v. Northeast Airlines, Inc., 9 N.Y.2d 34, 172 N.E.2d 526, 211 N.Y.S.2d 133 (1961). Since the basic law is the law of the forum, it is not required to incorporate the "whole law" of another state, but can fashion a rule of decision, using as a model some of that law in combination with its own law. See Cook, The Logical and Legal Bases of the Conflict of Lazes, 33 YALE L.J. 457, 480-85 (1924). See also Sedler, supra note 13 , at 31-34.

247. This, of course, is the position taken by the Restatement (Second). See notes 228-30 supra and accompanying text. 
the justification is that the lender should be protected from severe sanctions, it may be asked why he should be given more protection in interstate loan contracts than he is afforded in domestic transactions. No convincing answer has ever been given or even attempted, and the practice of the courts may simply reflect a bias in favor of lenders as a class.

It is far more reasonable to deal with usury cases in terms of policy and fairness, and this is especially important in view of the very strong policy that usury laws often represent. The forum should apply its own law where it has a real interest in doing so-for example, where the borrower is a resident of the forum or the lender has his place of business there. At the same time an effort should be made, as in all contract cases, to avoid conflicts by a more moderate and restrained interpretation of the policy or interest of one state. This is particularly true where there may be some danger of unfairness if the law of one or the other state is applied. This approach can be illustrated by a consideration of some usury cases in which the policies and interests of the concerned states were fairly clear.

In Trinidad Industrial Bank v. Romero, ${ }^{248}$ the lender was a Colorado corporation which maintained its principal place of business in the state. The borrowers, residents of New Mexico, executed a note secured by New Mexico property. Two and one-half years later-after the borrowers had missed two payments-the lender telephoned them and requested a "side note" to take account of the past due payments. One of the borrowers obtained a promissory note and a deed of trust form at the lender's office in Colorado and took them across the state line, where they were signed in blank by the other borrower. They were then taken back to the office in Colorado and signed, after which the lender filled in the amount due. The second note provided for $10 \%$ add-on interest (i.e., $10 \%$ of the principal amount borrowed multiplied by the fiveyear term of the loan); this amount was then broken down into sixty equal monthly payments. This resulted in an effective rate of interest on the unpaid balance of $10 \%$ for the first year, $12.5 \%$ for the second year, $17 \%$ for the third year, $25 \%$ for the fourth year, and $50 \%$ for the principal remaining due at the beginning of the fifth year. Suit was brought in New Mexico on the second note, which was clearly invalid under New Mexico law. The lender asserted that the interest charged was permissible under Colorado's usury statutes. The court purported to apply the Second Restatement test of section 203(2) and found that New Mexico was "the state of the otherwise applicable law." Concluding that the rate of interest was "greatly in excess of that allowable under our [New Mexico] law,"249 it declared the note invalid. The New Mexico statute specifically prohibited add-on provisions and provided for the forfeiture of all interest where the contract was usurious. The transaction was 
exactly the kind that the statute was designed to prohibit; New Mexico's interest in applying its law to protect its domiciliary borrower was clear; and the application of its law was certainly not unfair to the Colorado lender, who had entered into a loan contract secured by New Mexico land.

Now let us suppose that the case had arisen in Colorado and that under Colorado law the add-on provisions were valid. ${ }^{250}$ Under the Restatement approach, since the rates were "greatly in excess" of that allowed by New Mexico, it would be necessary for Colorado to decide whether New Mexico was the state of the most significant relationship. ${ }^{251}$ There were substantial factual contacts with both states, and Colorado, if it desired to apply its law, could plausibly argne that it was the state of the most significant relationship. That kind of analysis, however, obscures the real issue: whether Colorado will allow its lender to obtain a much more favorable rate of interest than could a New Mexico lender when dealing with New Mexico borrowers in a transaction secured by New Mexico land. Colorado might well decide to adopt a more moderate and restrained interpretation of its own policy and interest and to apply New Mexico law. But if it were to apply Colorado law, there would be no "fundamental unfairness," since the borrowers were aware that they were dealing with a Colorado lender, and the negotiations and performance were connected with both states. ${ }^{252}$

Similarly, in Oxford Consumer Discount Co. v. Stefanellit ${ }^{253}$ the borrowers, residents of New Jersey, obtained a loan on the security of their home from a Pennsylvania lender not authorized to do business in New Jersey. The note was executed at the lender's office in Philadelphia. The New Jersey court held that the loan was subject to the provisions of the applicable New Jersey statute, under which the interest was excessive and the contract completely unenforceable. Under a corresponding Pennsylvania law, the contract was fully valid. In holding that New Jersey law was applicable, the court looked to the legislative policy reflected in the statute and concluded that the legislature intended it to be applicable to all loans secured by New Jersey realty. ${ }^{254}$

250. We will assume either that the borrower was personally served there or was subject to jurisdiction under a "long-arm" statute.

251. New Mexico, applying the Restatement rule, assumed that it was that state.

252. Raton, New Mexico and Trinidad, Colorado are in close proximity and presumably make up a functional socio-economic and mobility area. See note 193 supra.

253. 102 N.J. Super. 549,246 A.2d 460 (1968), rehearing granted and decree modificd, 104 N.J. Super. 512, 250 A.2d 593 (1969), modified and aff'd, 55 N.J. 489, 262 A.2d 874, appeal dismissed, 400 U.S. 808 (1970).

254. The court considered whether the statute contained a "directive on choice of law" within the meaning of section $6(1)$ of the Restatcment (Second) and concluded that it did not. The court also examined the Restatement rule of section 195, to the effect that the state of the most significant relationship with respect to contracts for the repayment of money is ordinarily the state where repayment is to be made. It then referred to the "relevant policies of the forum" and concluded that it would follow this guideline, "not inerely beeause it was embodied in the Proposed Official Draft but for the reason that it is inherently sound." Id. at 563,246 A.2d at 467 . 
It also rejected the lender's rather specious argument that application of the New Jersey statute was unconstitutional. ${ }^{255}$

Both of these cases involved consumer loans, and in each of them the borrower's home state had a strong interest in applying its law to protect him against overreaching on the part of a foreign lender. Because of this interest, it may be expected that the courts of the borrower's home state will pay little deference to the less stringent requirements of foreign usury laws and that they will not be swayed by arguments in favor of a rule of validity. ${ }^{258}$ Similarly, when the contract is usurious under the laws of both states, and the borrower's state imposes a heavier sanction, its courts should also apply local law to implement the strong legislative policy reflected by that sanction.

When the contract is usurious under the law of the lender's state but not under the law of the borrower's state, a different kind of analysis is called for. It may be urged that the lender's state has an interest in applying its law against him-at lcast if the transaction was entered into there-in order to implement the admonitory policy reflected by its law. By the same token, it might be argued that the borrower's state has an interest in applying its law to allow the out-of-state lender to recover in order to encourage the making of loans to its residents. In Lyles v. Union Planters National Bank of Memphis, ${ }^{257}$ the lender was a Tennessee bank with a branch office on the Arkansas side of the state line. It was there that the contract was signed and that the note was to be paid. At the time of the execution of the contract, the borrower lived in Tennessee; by the time of suit he had moved to Arkansas, where the action was instituted. The note covered the financing of an automobile that had been purchased in Arkansas. Under Arkansas law, the contract was usurious and completely unenforceable. The court applied Arkansas law, but solely on the ground that the contract had been made there. This case has been analyzed in terms of borrower protection, and it has been argued that while Arkansas might have been justified in applying its law as to the rate of permissible interest because of the borrower's change of residence, it was not justified in

255. Id. at 566-76, 246 A.2d at 469-74. The lender relied on equal protection, due process, interstate commerce and full faith and credit. These arguments were clearly specious under the interest and fairness test. See Clay v. Sun Ins. Office, Ltđ., 377 U.S. 179 (1964).

256. See, e.g., Jones v. Tindall, 216 Ark. 431, 226 S.W.2d 44 (1950); Atlas Subsidiaries, Inc. v. O \& O Inc., 166 So. 2d 458 (Fla. App. 1964). In both of these cases the lender mistakenly included a choice-of-law provision looking to the law of the borrower's home state. Under the Second Restatement rationale this would not matter-it was presumably inserted by "mistake"-and the rule of validity would operate to rectify it. The Restatement treats Atlas as a case in which the other state was one that had "no substantial relationship to the contract." Restatement (SECOND), Explanatory Notes $\$ 203$ comment $c$, at 655 . The borrower had its home office in Pennsylvania and the note was made payable there. This element of the obligation could be said to have been "manipulated," but, on the other hand, it seems a logical place for payment to be made. It is doubtful that the result would have been any different had "more occurred" in Pennsylvania.

257. 239 Ark. 738, 393 S.W.2d 867 (1965). 
applying its more severe sanction on that basis. ${ }^{258} \mathrm{I}$ disagree with this view and would contend that Arkansas should have applied its law even if the borrower had not moved to that state. Arkansas should not allow branch offices of outof-state banks to exact a higher rate of interest than purely local banks can charge. Whenever a court perceives an admonitory policy behind the usury law-as indeed it should when, as here, severe sanctions are imposed-that policy should be applicable to all lenders who transact business in that state, irrespective of the residence of the borrower. On the other hand, when the forum's usury law imposes a mild sanction, such as forfeiture of excess interest, it can be contended that an admonitory policy is not present and that if the contract is valid under the law of the borrower's state, it should be enforced. ${ }^{260}$ There is a heavy enough burden imposed in holding the lender to a different standard when he deals with a foreign borrower in the latter's home state. When the situation is reversed, even the courts of the borrower's state should enforce no more stringent limitations than the lender would face in his home state-where, after all, the transaction occurred.

Another question of significance is whether there are circumstances in which the borrower's home state should not apply its law for his protection. It has been held that when the borrower seeks out the lender in the latter's home state, the lender should be able to charge the locally permissible rate of interest. In Dairy Equipment Co. of Utah v. Boehme, ${ }^{260}$ an Idaho buyer was unable to secure local financing for the purchase of dairy equipment for his farm. The Utah seller obtained the financing from a Utah bank, ${ }^{261}$ the contract was executed in Utah, and payments were to be made there. The Idaho court, emphasizing that there was no intent to evade Idaho law, upheld the contract under Utah law. ${ }^{262}$ I agree with the result. This is a case calling for a moderate and restrained interpretation of the forum's policy and interest. Though it might not be "fundamentally unfair" to hold the Utah lender to Idaho law, since he knew where the buyer resided, ${ }^{263}$ it does seem that the lender should be able to rely on the standards established by the law of his home state when he makes no attempt at out-of-state solicitation. ${ }^{264}$ It has been contended that a distinction should be drawn between consumer borrowers and those whose bargaining power may be equal to that of lenders, and that the former need the protection of their home state even when they have solicited an out-of-state loan. ${ }^{265}$ While this may be true, the position of the lender must also be con-

258. See Comment, supra note 216 , at 247-49.

259. Contra, id. at $190-92$.

260. 92 Idaho 301, 442 P.2d 437 (1968).

261. The facts are set out at length. Id. at 302, 442 P.2d at 438.

262. Accord, Whitman v. Green, 289 F.2d 566 (9th Cir. 196i).

263. See Comment, supra note 216 , at $243-44$.

264. See A. EnrenzweIG, Conflicts in A Nutsheli 179-80 (2d ed. 1970).

265. See Comment, supra note 216 , at 244-45. 
sidered. The lender was acting in accordance with his state's standards, and he was not soliciting in the buyer's state in the hope of making a profit there.

On the other hand, where the out-of-state lender solicits business in the borrower's home state, the borrower's state should apply its own law. In Burr v. Renewal Guaranty Corp., ${ }^{268}$ a Colorado corporation advertised its loans in trade journals. An Arizona borrower responded to the advertisement, and the loan was negotiated by mail.267 The note was usurious under Arizona law, but not under Colorado law. The Arizona court applied the new Restatement's rule of validation and upheld the note, observing that neither bad faith nor intent to avoid the application of Arizona law had been shown. ${ }^{268}$ This is a closer case. If the lender had maintained a branch office in Arizona and had solicited loans through local newspaper advertisements, Arizona would have considered this a domestic case and applied its own law. ${ }^{269}$ If there had been direct mail solicitation, a similar result might have followed, based upon a strong policy against usury. ${ }^{270}$ But here there was no direct solicitation of Arizona residents. Instead there was a general solicitation in a magazine of nationwide circulation. Viewed in this light, the result may be justified. Nevertheless, the case should have been approached in terms of these considerations rather than disposed of by the facile invocation of a rule of validity.

Most of the cases considered thus far have dealt with consumer rather than commercial borrowing, ${ }^{271}$ and it may be asked whether a different approach should be taken when a corporate or "experienced individual" borrower is involved. My view is that it should not. If a corporation is precluded from asserting the defense of usury by the law of its state of incorporation (or, more realistieally, by the law of the state where it has its principal place of business), there is certainly no reason to allow it to assert the defense when sued on a "foreign" obligation. ${ }^{272}$ But when the law of the corporation's "home

266. 105 Ariz. 549, 468 P.2d 576 (1970).

267. The advertisement appeared in a life insurance trade journal. The lender specialized in loans to life insurance salesmen secured by commissions earned by them but not yet due from their companies. The borrower was a life insurance salesman who had accrued future commission rights. The note was prepared in Colorado and sent to the borrower in Arizona together with an assignment of his future commissions. He signed the documents there and returned them by mail to the lender, who then mailed its check to him. There was an express provision for the application of Colorado law.

268. It emphasized that the lender had charged less than it was entitled to under Colorado law. 105 Ariz. at 559, 468 P.2d at 577.

269. See RESTATEMENT (SECOND), Explanatory Notes $\$ 203$, comment $c$, at 651 ; $c f$. Lyles v. Union Planters Nat'1 Bank, 239 Ark. 738, 393 S.W.2d 867 (1965).

270. Cf. Restatement (Second) § 192.

271. Crisafulli v. Childs involved commercial borrowing, which, as the court indicated, may, have influenced the decision. 33 App. Div. 2d 293, 297, 307 N.Y.S.2d 701, 705 (4th Dep't 1970).

272. This would certainly be true of individual borrowers. The fact that the state where the loan was transacted allowed corporations to assert the defense could not in itself be said to represent an admonitory policy apart from the usurious nature of the transaction. If the loan was not usurious under the law of that state, the state would have no interest in applying its law to implement its usury policy. 
state"273 would allow it to assert the defense and the transaction is usurious under that state's law, should the home state's policy be put aside in an interstate case merely because the borrower is a corporation ?274 It has been asserted that in practice this is exactly what has happened, ${ }^{275}$ and the result is said to be justified on the ground that the lender and the corporate borrower are likely to have equal bargaining power. ${ }^{278}$ Yet this approach is highly questionable. The policy reflected in the law of the corporation's home state is that commercial borrowers $d o$ need protection against usury. Thus, the state's interest in applying its law is no weaker in the case of a corporation than in the case of an individual. Indeed, the interest may be stronger, since the legislature may also have been concerned about the outflow of corporate capital in the form of debt service payments to foreign lenders. The only difference that I see between the consumer and the cominercial borrower is that when a corporation is involved, the forum may be more disposed to a moderate and restrained interpretation of its own policy and interest because of the equality of bargaining power between the borrower and the lender. ${ }^{277}$ But it should only do so on that basis and should not apply a blanket rule of validity to commercial loans, in disregard of established legislative policy.

In summary, the rule of validity in usury cases cannot be justified either on the ground that the difference in interest rates is not significant or on the assumption that courts should avoid the imposition of heavy sanctions against the lender in an interstate loan situation. When the contract is usurious under the law of the forum and the borrower is a resident of the forum, the forum should apply its law to protect him, except if the borrower sought out the lender in the lender's home state and the lender was entitled to rely on the law of that state. When the contract is not usurious under the law of the borrower's state but is usurious under the law of the lender's state, the result may depend upon whether the law of the lender's state represents a strong admonitory policy, as reflected by the imposition of a severe sanction. If it does not represent such a policy, the defense of usury should not be sustained, since the only state interested in protecting the borrower does not do so. ${ }^{278}$ When an admonitory policy is clear, however, the lender's state may have a real

273. This would be the state where it had its principal place of business or where its activities in connection with the loan were conducted.

274. For these purposes, "experienced individual borrowers" may be equated with corporations.

275. See Comment, supra note 216, at 210-11.

276. Id. at 212-14.

277. See Consolidated Jewelers, Inc. v. Standard Fin. Corp., 325 F.2d 31 (6th Cir. 1963); cf. West Side Motor Express, Inc. v. Finance Discount Corp., 340 Mass, 669, 165 N.E.2d 903 (1960).

278. In terms of interest analysis, this would be considered the unprovided-for case. Since both states have a policy of upholding transactions and neither state has an interest in applying its law to protect the borrower, this common policy should be upheld and the defense denied. For a discussion of such an approach in the context of the defense of incapacity, see B. CuRRIE, supra note 35 , at $90-92$. 
interest in applying its law to effectuate that policy if some of the events occurred there. Conversely, the borrower's state may have an interest in allowing the out-of-state lender to recover under its more liberal law because it wishes to encourage the in-flow of foreign capital. ${ }^{279}$ An analysis of usury problems by this method, it is submitted, will produce sound results by enabling the courts to focus on the important considerations of policy and fairness. A rule of validity is totally irrelevant and merely serves to obscure the real issues.

\section{CONCLUSION}

In this article I have sought to analyze the approach of the Restatement (Second) to the solution of contracts problems against the backdrop of my own view of judicial method and the policy-centered conflict of laws. The Restatement distinguishes between the case in which the parties have made an effective express choice of law and the situation in which they have not. It would fully uphold the parties' express choice of law as to matters within their contractual capacity and would also uphold it as to matters beyond their contractual capacity with certain limited exceptions. When the parties have not made an effective choice of law, it would determine all questions-both those involving matters within the contractual capacity of the parties and matters beyond their contractual capacity-with reference to the concept of the most significant relationship. That concept represents an amalgam of policy considerations and factual contacts; but it is enunciated in the form of a localizing rule, emphasizing factual contacts.

As I have suggested, a proper solution of contracts problems requires that one distinguish between, on the one hand, matters within the contractual capacity of the parties or matters that (while analytically beyond their contractual capacity) do not involve any strong policy and, on the other, matters involving a strong policy of the forum or other concerned state. As to the former, I would give effect to the parties' express choice of law in all cases, except that, as to matters theoretically outside their contractual capacity, I would not recoguize such a choice where one party could not be considered in any way to have assented to the choice. But since I would not recognize express choice of law as to any matter involving a strong policy, my approach in this regard differs markedly from that of the Restatement.

When the parties have not made an express choice of law, the state-of-themost-significant-relationship concept is useful only insofar as its localizing methodology can be used to determine implied intent. Whenever possible, I would utilize implied intent in the same manner as I would employ express choice of law-to determine matters within the contractual capacity of the

279. As previously indicated, usury laws may have significant economic consequences. See text accompanying notes $227-30$ supra. 
parties and matters that do not involve any strong policy. Most cases, however, will involve significant policy considerations, and here I would submit that the localizing approach of the state-of-the-most-significant-relationship rule merely serves to obscure the real issues. I would decide those cases, as I would any other, with reference to considerations of state policy and fairness to the parties. However, because of the possibility of reliance on the law of a particular state and because of the common policy of all states to protect the legitimate expectations of the parties and to insure the stability of interstate commercial transactions, the displacement of the forum's law will be more frequent in the contracts area than, for example, in tort cases. Nonetheless, in the case of a true conflict, the forum should apply its own law if no unfairness would result to either party. Finally, I would deal with usury cases on this same basis, without reference to what I believe a completely unjustifiable rule of validity.

If contracts is "the most complex and confused area of choice of law problems," 280 the complexity and confusion is not obviated by the approach taken in the Restatement (Second), and indeed, may even be compounded by it. I fear, however, that my own efforts may have been no more successful. In the final analysis, we can perhaps do no better than to recall the words of Justice Roger Traynor:

The responsible court will have to be on its mettle. It must be prepared to reject unrealistic rules, yet cautious enough not to make formulations that reach too zealously into the future or give too zealous a scope to local policy. It must distinguish between real and spurious conflicts at the outset. It must temper its freedom to declare local policy and its scope with a sense of harmonious interstate relations as well as for the justifiable expectations of the parties. ${ }^{281}$

These words are particularly applicable to the responsibility of a court when confronted with a case in which a contract has cut across state lines.

280. See note 1 supra.

281. Traynor, Is This Conflict Really Necessary?, 37 TEx. L. Rev. 657, 675 (1959). 